\title{
Portuguese living standards, 1720-1980, in European comparison: heights, income, and human capital
}

\author{
By YVONNE STOLZ, JOERG BATEN, and JAIME REIS*
}

\begin{abstract}
When and why did the Portuguese become the shortest Europeans? In order to find the answer to this question, we trace the trend in Portuguese living standards from the 1720 s until recent times. We find that during the early nineteenth century average height in Portugal did not differ significantly from average height in most other European countries, but that when, around 1850, European anthropometric values began to climb sharply, Portugal's did not. In a panel analysis of 12 countries, we find that delay in human-capital formation was the chief factor hindering any improvement in the biological standard of living in Portugal.
\end{abstract}

$\mathrm{I}_{\mathrm{e}}^{\mathrm{t}}$ t was Portugal's fifteenth- and sixteenth-century seafaring scientists and explorers who placed this small country at the cutting edge of maritime science and navigation and thereby transformed the global status of the rest of Europe as well. Their expeditions along the African west coast and to Latin America, not to mention Vasco da Gama's discovery, on his first voyage (1497-9), of the sea route to India, transformed their contemporaries' consciousness of the world that lay beyond the horizon. However, since those glory days the Portuguese have come to feel that their country lags behind the rest of Europe-and they are right, if anthropometry is taken as a welfare indicator: recent data indicate that the Portuguese are on average shorter than any other European nationality. ${ }^{2}$ When and why did the Portuguese slip to last place in the European height race?

To tackle this question, a two-step approach is adopted. First, height development is reconstructed over almost three centuries, from the 1720 s to the $1980 \mathrm{~s}$, and it is found that at the beginning of that time span Portuguese heights were in

\footnotetext{
* Author Affiliations:Yvonne Stolz, University of Tuebingen; Joerg Baten, University of Tuebingen and CESifo; Jaime Reis, University of Lisbon, Institute of Social Sciences.

${ }^{1}$ We thank Pedro Lains, Nikola Koepke, John Komlos, Nicholas Meinzer, Julia Muschallik, Richard Steckel, the anonymous referees, and participants in the 2009 World Economic History Congress, the Eighth Conference of the European Historical Economics Society, and the Graduate Workshop for Economic and Social History, Nuffield College, Oxford, for their comments on earlier versions, their suggestions regarding data, and other helpful input. We are also grateful to the 'Prices, Wages and Rents in Portugal, 1500-1900' project at the University of Lisbon (ICS), which made available unpublished information on Portuguese wages and prices, and to Ramon Ramon, for his help with the Spanish data. Financial support from the ESF GlobalEuroNet programme and the EU-HIPOD programme is also gratefully acknowledged. Julie Smith improved the English style.

${ }^{2}$ The height of Portugal's 1980s birth cohort (today in their 20s) is $172.1 \mathrm{~cm}$, whereas that of Europe as a whole is $176.9 \mathrm{~cm}$. Moldovans are in second-to-last place, at $174.2 \mathrm{~cm}$; Sobral, 'Secular changes', p. 496; J. Baten and M. Blum, 'Global height trends and its determinants, 1810-1984: an overview', University of Tuebingen working paper (2011), http://www.wiwi.uni-tuebingen.de/lehrstuehle/volkswirtschaftslehre/wirtschaftsgeschichte/ research/downloads.html (accessed on 31 March 2010). For Portuguese data see Padez and Johnston, 'Male adult height', p. 292; Padez, 'Secular trend', p. 18; Reis, 'Crescimento económico', p. 160; idem, “"Urban premium”', p. 79.

(C) Economic History Society 2012. Published by Blackwell Publishing, 9600 Garsington Road, Oxford OX4 2DQ, UK and 350 Main Street, Malden, MA 02148, USA.
} 
line with European heights generally. Second, in an attempt to establish the possible causes of this evolution, real-wage development and human-capital formation are focused on as possible factors, resulting in the discovery that it was the sluggish pace in Portugal of both real-wage convergence and human-capital formation that was the culprit.

More specifically, a number of previously unexploited resources have been assembled: a data set spanning 11 birth decades, from the 1720 s to the 1830 s, providing the first anthropometric documentation on eighteenth-century Portugal, and new regional data that complement those previously available for heights up until $1910 .^{3}$ No new sources are needed for the period 1910-80, thanks to the comprehensive height statistics recorded by Sobral ${ }^{4}$ and Padez. ${ }^{5}$

Taken together, these sources enable us to compare Portuguese stature with that of a sample from other European countries over the very long run and thus determine the timing and extent of the divergences among their respective biological living standards. It turns out that the Portuguese standard of living stagnated after 1840, at a time when other European regions developed sustained upward trends. It was thus in the 1890s that the Portuguese came to be the shortest population in Europe.

Having added Portugal as a very important case to the European dataset of height, it is possible to perform a long-run panel data analysis on the determinants of the biological standard of living for 12 European countries. Human capital, real wages, urbanization, and social policy are added as potential determinants, to which new information on relative food prices for a sample of European countries is added as a further potential determinant.

This article is composed of six sections. In the first, the height data are introduced, followed by an estimate of the Portuguese height trend for the period 1720-1910 in section 2 . In the third section this estimate is compared with a sample of other European countries in order to determine whether the Portuguese have always been shorter than other Europeans, a determination that contributes to our knowledge of the biological standard of living throughout Europe. Section 4 presents a major extension, back to 1720 , of the existing series for Portuguese real wages and other possible determinants of biological welfare. ${ }^{6}$ These potential determinants are tested using panel OLS regressions in section 5. In the sixth and last section some conclusions are offered.

Our data set spans nearly three centuries of Portuguese height development, if we include the twentieth-century data already studied by other authors. ${ }^{7}$ While there have been height-development studies based on archaeological evidence which have covered even longer periods, this is the first time that such a long time span has been treated in a single article based on archival height records - a treatment possible only because military records preserved in various archives throughout

\footnotetext{
${ }^{3}$ Reis, “'Urban premium””, p. 79; idem, 'Crescimento económico', p. 160.

${ }^{4}$ Sobral, 'Secular changes', p. 496.

${ }^{5}$ Padez, 'Secular trend', p. 18.

${ }^{6}$ Original estimates for Portuguese numeracy during the early eighteenth century, based on Inquisition records, are provided, as well as fresh data on nineteenth-century infant mortality.

${ }^{7}$ Sobral, 'Secular changes', p. 496; Padez, 'Secular trend', p. 18.
} 
Table 1. Number of cases by recruitment decade and by birth decade

\begin{tabular}{|c|c|c|c|}
\hline Recruitment decade & $N$ & Birth decade & $N$ \\
\hline 1760 & 822 & 1710 & 1 \\
\hline 1770 & 184 & 1720 & 47 \\
\hline 1790 & 675 & 1730 & 285 \\
\hline 1800 & 226 & 1740 & 525 \\
\hline 1820 & 417 & 1750 & 206 \\
\hline 1830 & 528 & 1760 & 301 \\
\hline 1840 & 468 & 1770 & 426 \\
\hline 1850 & 3,487 & 1780 & 143 \\
\hline 1860 & 5,574 & 1790 & 166 \\
\hline 1870 & 8,541 & 1800 & 331 \\
\hline 1880 & 10,860 & 1810 & 424 \\
\hline 1890 & 2,633 & 1820 & 596 \\
\hline 1900 & 4,034 & 1830 & 4,029 \\
\hline 1910 & 3,058 & 1840 & 5,144 \\
\hline 1920 & 2,819 & 1850 & 9,794 \\
\hline \multirow{6}{*}{1930} & 2,314 & 1860 & 9,530 \\
\hline & & 1870 & 2,653 \\
\hline & & 1880 & 3,872 \\
\hline & & 1890 & 3,161 \\
\hline & & 1900 & 2,703 \\
\hline & & 1910 & 2,303 \\
\hline Total & 46,640 & Total & 46,640 \\
\hline
\end{tabular}

Notes: In this compilation, recruits aged younger than 18 or older than 50 were excluded, as were extreme heights $(<140 \mathrm{~cm}$, $>200 \mathrm{~cm}$, although the latter extreme was not reached).

Sources: Arquivo Distrital do Porto, Porto, archival signature code: Recenseamento PT/ADPRT/AC/GCPRT (310 cases); Arquivo Geral do Exército, Lisbon, archival signature code: Livros de Recenseamento (3,545 cases); Arquivo Histórico Militar, Lisbon, archival signature code: Livros de Recenseamento, AHM/DIV/3/08/3/12 (2,841 cases); Arquivo Distrital de Évora, Évora, archival signature code: Recenseamento (3,140 cases); Reis, 'Crescimento económico', and idem, "Urban premium”' (36,804 cases).

Reis's works are based on archival sources from the Arquivo Nacional da Torre de Tombo, Lisbon.

Portugal contain high-quality information dating as far back as the eighteenth century (see notes to table 1). Drawing on the Arquivo Histórico Militar (Lisbon), we have collected large samples for the recruitment years 1763 and 1791, and a few smaller ones for the intervening years, as well as substantial samples for the 1820 s -40 s (table 1). We thus have a sufficient number of observations for all of the birth decades under consideration, with the exception of the number, slightly below our minimum, for the first of those decades, that of the $1720 \mathrm{~s}^{8}{ }^{8}$ For each of the birth decades from the 1830s onwards, we were able to collect a large sample thanks to an increased abundance of height information. In particular, we extended the already well-documented post- 1857 measurement period data set ${ }^{9}$ by 3,545 observations from the north of Portugal (Viana do Castelo, Braga, and Porto) preserved in the Arquivo Geral do Exércíto (Lisbon), to which we have added observations from the district archives of Évora, Faro, and Porto.

This data set, based on conscription records (universal military service having been introduced in 1857), has been standardized to six Portuguese districts as they existed in the eighteenth century. ${ }^{10}$ The fact that the sample spanning the second

\footnotetext{
${ }^{8}$ With the exception of the 1720 s $(\mathrm{N}=47)$, we include only those birth decades for which at least 50 cases per recruitment regime (see below for the definition of recruitment regimes in Portugal) are available; in most cases, $\mathrm{N}$ is far higher.

${ }^{9}$ Reis, “"Urban premium”', p. 79; idem, 'Crescimento económico', p. 160.

${ }^{10}$ Minho, Trás-os-Montes, Beira, Estremadura, Alentejo, and Algarve. 
half of the nineteenth century provides thorough coverage, being representative of the sampled districts, means that when estimating the time trends for the entire period under study we can control for geographical composition.

We exclude extreme heights (below 140 and above 200 centimetres $^{11}$ and analyse only those recruits from 18 to 50 years of age, thereby excluding all those who were still growing or already shrinking. We include dummy variables for ages $18-22$, to control for late growth. Despite all of these precautions, our data feature several internal discrepancies, the most important of which is due to modifications over the years in the Portuguese military's minimum-height requirement.

Prior to the introduction of the military draft in 1857 , the only men whose heights were recorded in military records were those who not only passed the military's minimum height requirement (MHR) but actually served; hence the height evidence is truncated below the MHR. How does this truncation affect the selectivity of our data? The fact that the distribution falls sharply below 62 polegadas, or inches, in 1763 and 1774 suggests that this was the cut-off point at that time (figure 1, panel a). From 1776 to 1807 the height evidence is truncated at 60 polegadas but reveals, on the right side of the distribution, the presence of a grenadier contingent $(n=169)$ composed of men chosen for their exceptional stature (figure 1, Panel b). The period 1820-56 features two jumps, from 56 to 57 polegadas and then from 57 to 58 polegadas (figure 1, panel c). Thus it seems that prior to 1857 three successive MHRs were applied: between 1763 and 1774, 62 polegadas; between 1776 and 1807, 60 polegadas; and after 1820,57 polegadas. ${ }^{12}$ A review of the main regulations governing this issue indicates that this was indeed the case. ${ }^{13}$ Finally, in 1857, with the establishment of general conscription, an MHR of 155 centimetres (56.8 polegadas) was established, and later, in 1887 , reduced to 154 centimetres (56.6 polegadas).

The introduction, in 1852, of the metric system is another complication that has proved to be problematic for researchers. A thorough account of this problem of conversion and how it was overcome can be found in appendix I. Since the general conscription regulations required all conscripts to undergo a physical examination that included having their height measured, the sample includes those who failed to meet the MHR or any other aspect of this examination. To control for the variations in the MHR prior to 1857, we use a truncated maximum likelihood method with varying lower limits, but we use simple OLS regression techniques for subsequent years because after 1857 the height evidence does not suffer from truncation.

According to Dores Costa, military recruitment was extremely unpopular among the Portuguese during the eighteenth century. ${ }^{14}$ Because both formal and

\footnotetext{
11 The latter extreme was not reached.

${ }^{12}$ We performed truncated regressions with Stata 10, using 62, 60, and 57 inches (polegadas) as truncation points.

${ }^{13}$ The 1762 regulation of Count Lippe, Portugal's Prussian great military reformer, stated that 62 polegadas was the MHR. In 1776, the Marquês de Pombal decreed a reform and an enlargement of the army; Selvagem, Portugal militar. Although Selvagem does not refer to any change in the MHR at this time, it seems likely that this enlargement could have been achieved only by means of a broader recruitment base. A lower MHR, such as the 60 polegadas detected in the histogram of fig. 2, panel $\mathrm{B}$, therefore seems plausible. The next documented MHR, established by the Parliament in 1823 , was 57.5 polegadas and also matches the available evidence. See Diario, p. 331.

${ }^{14}$ Dores Costa, Insubmissão, pp. 121-55.
} 
A

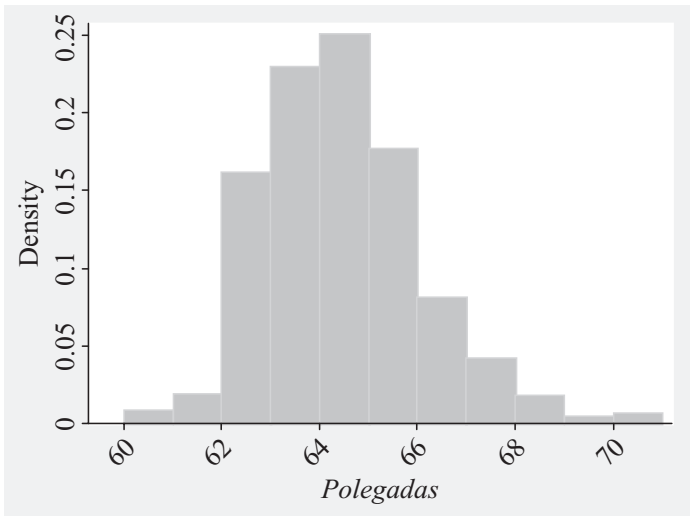

B

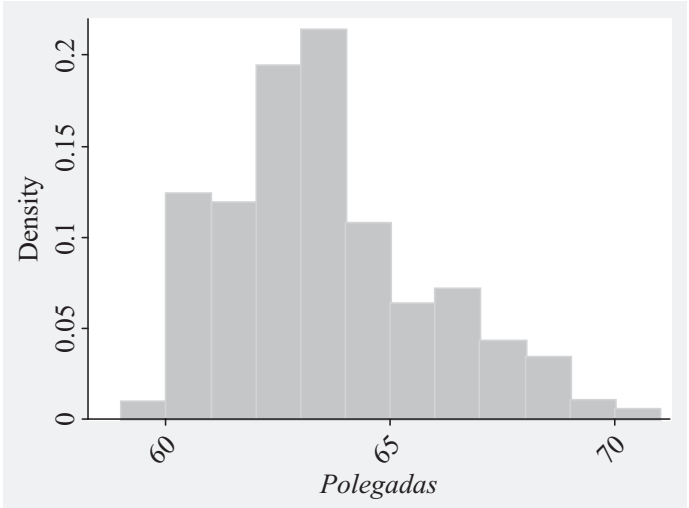

$\mathrm{C}$

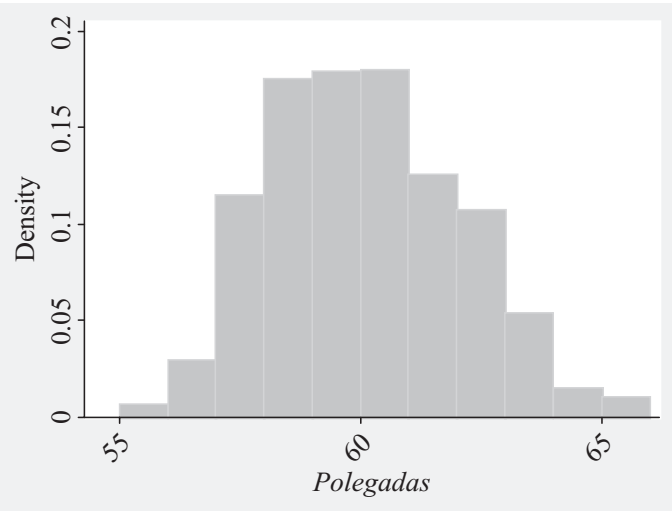

Figure 1. Panel A: Histogram of polegadas, recruitment period 1763-74. Panel B: Histogram of polegadas, recruitment period 1776-1807. Panel C: Histogram of polegadas, recruitment period 1820-56

Sources: See tab. 1. 
informal protection networks enabled many ordinary persons as well as many of those in the upper social strata to avoid recruitment altogether, data on these individuals, including but not limited to their heights, are slightly less frequent in the military records. Thus it is far more likely that those soldiers who actually served were (after one has factored in the MHR) either a slightly negative or a relatively unbiased sample of recruitment-age males during the eighteenth century.

\section{II}

Given the complexity of the underlying data, several precautions are required in order to avoid introducing biases into an estimation of the Portuguese height trend for the period 1720-1980. Our estimation takes into account these problems and their resolution (table 2). The independent variables used include controls for army category, birth decade, age, and occupational and regional composition.

The trend is estimated by recruitment periods based on their different MHRs as defined in the previous section: 1763-74, 1776-1807, 1820-56, and 1857-1932. We aimed at running separate maximum likelihood truncated regressions for each recruitment regime. This would have been ideal, but would have required a greater number of individual observations per birth decade than we had for the first four of these. Our solution therefore was to combine the first two periods (table 2, column 1). ${ }^{15}$ When we compared this combined regression with the one for the single recruitment period 1776-1807 (table 2, column 2), we found that the trends for the overlapping period were almost identical (table 2, columns 1 and 2; and appendix II) and therefore concluded that the resulting time dummy coefficients could be used for the trend estimate (table 2, column 2).

Catch-up growth, for which we controlled with age dummies, correlates with changes over time in the biological standard of living in Portugal. ${ }^{16}$ The constant and the birth-decade coefficients in combination with the coefficients of the age dummies revealed that the tallest recruits were found among the earliest group of recruits (column 2); shorter ones were found in the next period (column 3), and the shortest in the last one (column 4). Column 2 also featured most of those who achieved their final height earliest; after the age of 18 their coefficients were no longer significant. The fact that in the last period (1857-1932) age dummies remained quite large and significant up to 21 and 22 years of age is in line with previous studies indicating that stunted individuals tend to undergo relatively late catch-up growth during their early adult years. ${ }^{17}$

Birth-decade dummies and a constant were employed to generate an adjusted time trend that avoids the distortions associated with age, military rank, region, and occupation. For example, the constant in column 2 yielded an estimate for a recruit from the district of Estremadura who belonged to the 1780s birth cohort (164.01 centimetres). Adding the coefficient for the birth decade of the $1750 \mathrm{~s}$ (1.21), we obtain 165.22 centimetres, and so on for the other birth decades. We

\footnotetext{
${ }^{15}$ In the truncated regression model implemented in the Stata software, several truncation points can be combined in one command.

${ }^{16}$ To control for catch-up growth, we experimented with age dummies for the 24-30-year age range and found no significant difference from adult height (the reference category). Controlling for early shrinking with an age dummy for the 45-50-year age range yielded no significant results either.

${ }^{17}$ Steckel, 'Stature', p. 1908; Komlos, 'Shrinking', p. 702. 
PORTUGUESE LIVING STANDARDS

Table 2. Estimation of the height trend in Portugal, 1720s-1910s

\begin{tabular}{|c|c|c|c|c|}
\hline & (1) & (2) & (3) & (4) \\
\hline Recruitment regime & $1776-1807$ & $1763-74$ and $1776-1807$ & $1820-56$ & $1857-1932$ \\
\hline \multicolumn{5}{|l|}{$\begin{array}{l}\text { Birth decades } \\
1720\end{array}$} \\
\hline 1730 & & $\begin{array}{l}(0.863) \\
1.01 \\
(0.158)\end{array}$ & & \\
\hline 1740 & $1.53 * *$ & $1.47^{* *}$ & & \\
\hline 1750 & $\begin{array}{l}(0.017) \\
1.44 * *\end{array}$ & $\begin{array}{l}(0.023) \\
1.21 *\end{array}$ & & \\
\hline 1760 & $(0.038)$ & $(0.083)$ & & \\
\hline 1770 & $(0.017)$ & $(0.021)$ & & \\
\hline 1770 & $\begin{array}{l}0.88 \\
(0.167)\end{array}$ & $\begin{array}{l}0.75 \\
(0.241)\end{array}$ & & \\
\hline 1800 & & $(0.241)$ & $1.10^{* * *}$ & \\
\hline 1810 & & & $\begin{array}{c}0.68 \\
(0.207)\end{array}$ & \\
\hline 1820 & & & $\begin{array}{l}0.22 \\
(0.701)\end{array}$ & \\
\hline 1830 & & & $7.85 * * *$ & $-0.62 * * *$ \\
\hline 1840 & & & & $-0.83^{* * * *}$ \\
\hline 1850 & & & & $-0.35 * *$ \\
\hline 1860 & & & & $-0.58^{* * * *}$ \\
\hline 1870 & & & & -0.22 \\
\hline 1880 & & & & $-0.72^{* * * *}$ \\
\hline 1890 & & & & $-0.58^{* * * *}$ \\
\hline 1900 & & & & $-1.10 * * *$ \\
\hline Age 18 & $-2.07 * * * *$ & $-2.08 * * *$ & $-1.62 * * *$ & $-1.12^{* * * *}$ \\
\hline Age 19 & -0.62 & -0.63 & $-0.98^{* *}$ & $-0.99^{* * *}$ \\
\hline Age 20 & $\begin{array}{l}(0.233) \\
-0.67\end{array}$ & $\begin{array}{l}(0.232) \\
-0.71\end{array}$ & $\begin{array}{l}(0.017) \\
0.27\end{array}$ & $\begin{array}{l}(0.000) \\
-0.84 * * *\end{array}$ \\
\hline Age 21 & $(0.150)$ & $(0.133)$ & $(0.500)$ & $(0.000)$ \\
\hline Age 21 & $\begin{array}{l}0.09 \\
(0.890)\end{array}$ & $\begin{array}{l}0.05 \\
(0.939)\end{array}$ & $\begin{array}{l}0.64 \\
(0.199)\end{array}$ & $\begin{array}{l}-0.72 * * * \\
(0.000)\end{array}$ \\
\hline Age 22 & -0.33 & -0.36 & -0.37 & $-0.47^{* *}$ \\
\hline Age 23 & -0.11 & -0.17 & $\begin{array}{l}(0.418) \\
0.47\end{array}$ & $\begin{array}{l}(0.026) \\
0.02\end{array}$ \\
\hline Age $45-50$ & $\begin{array}{l}(0.846) \\
-1.95\end{array}$ & $\begin{array}{l}(0.765) \\
-2.13\end{array}$ & $(0.367)$ & $(0.944)$ \\
\hline Age $43-50$ & $(0.425)$ & $\begin{array}{l}-2.13 \\
(0.395)\end{array}$ & & \\
\hline Grenadier & $\begin{array}{l}7.75 * * * \\
(0.000)\end{array}$ & $\begin{array}{l}7.22^{* * * *} \\
(0.000)\end{array}$ & & \\
\hline Officer & & & $\begin{array}{l}7.85^{* * * *} \\
(0.000)\end{array}$ & \\
\hline Semi-skilled & $\begin{array}{l}2.24 * * * \\
(0.001)\end{array}$ & $\begin{array}{l}1.45^{* *} \\
(0.018)\end{array}$ & $\begin{array}{l}2.70 * * * \\
(0.000)\end{array}$ & $\begin{array}{c}-0.23 * \\
(0.063)\end{array}$ \\
\hline Skilled & -0.57 & -0.40 & $-0.72 *$ & $0.56 * * *$ \\
\hline Semi-professional & $(0.137)$ & $(0.256)$ & $(0.071)$ & $(0.000)$ \\
\hline semi-protessional & $(0.591)$ & $(0.462)$ & $(0.428)$ & $(0.000)$ \\
\hline Professional & 0.81 & $0.93^{*}$ & $1.25^{*}$ & $1.80^{* * * *}$ \\
\hline Minho & $\begin{array}{l}(0.119) \\
-0.26\end{array}$ & $\begin{array}{l}(0.062) \\
-0.07\end{array}$ & $\begin{array}{c}(0.080) \\
0.80\end{array}$ & $\begin{array}{l}(0.000) \\
-0.43 * * *\end{array}$ \\
\hline & $(0.633)$ & $(0.887)$ & $(0.192)$ & $(0.000)$ \\
\hline Trás-os-Montes & $-3.79 * *$ & $-3.74^{* *}$ & -4.06 & $-1.17 * * *$ \\
\hline Beira & $(0.030)$ & $(0.019)$ & $(0.118)$ & $(0.006)$ \\
\hline Beira & -0.43 & -0.30 & -0.41 & $\begin{array}{l}-0.65 * * * \\
(0.000)\end{array}$ \\
\hline Alentejo & $2.52 * * *$ & $2.52 * * *$ & 0.06 & $0.31^{* *}$ \\
\hline Algarve & $\begin{array}{l}(0.000) \\
3.69 * * *\end{array}$ & $\begin{array}{l}(0.000) \\
4.18^{* * * *}\end{array}$ & $\begin{array}{l}(0.866) \\
-0.84\end{array}$ & $\begin{array}{l}(0.049) \\
0.28\end{array}$ \\
\hline & $(0.000)$ & $(0.000)$ & $(0.591)$ & $(0.401)$ \\
\hline Constant & $163.84 * * *$ & $164.01 * * *$ & $163.73^{* * * *}$ & $164.69 * * *$ \\
\hline Observations & $1,413^{(0.000)}$ & 1,734 & 1,971 & $\begin{array}{l}(0.000) \\
42,696\end{array}$ \\
\hline Wald $\mathrm{chi}^{2} / \mathrm{R}^{2}$ & 666.64 & 710.26 & 438.59 & 0.01 \\
\hline
\end{tabular}

Notes: $* * * * * *$ Significant at $10 \%, 5 \%$, and $1 \%$ levels. Constant for (1) and (2) refers to an infantry recruit born in the 1780 s in the Estremadura region, aged 24-50. Constant for (3) refers to the same, but born in the 1790 s. Constant for (4) refers to the same, but born in the 1910 s. 
used the constants and time coefficients in columns 3 and 4 to calculate estimates for the periods 1790-1830 and 1830-1910, respectively (that of 1830 is based on an average of columns 3 and 4). We then moved beyond Estremadura, calculating the population shares of all six regions of Portugal during the eighteenth and nineteenth centuries, and added or subtracted the weighted coefficients for the five other regions. For example, the coefficient for the Minho region, -0.079 , was multiplied by the Minho population share, 0.26, and added to the Estremadura height. The same calculation was performed on the other regions and resulted in regionally adjusted height estimates (table 3 ). ${ }^{18}$ Using this procedure, we obtain height estimates from which the effects of grenadier and similar military units, region, and age were removed.

It is important in our next analysis that the data for the recruitment periods before and after 1857 - and also before and after 1820 - are not severely sampleselected. Until we can determine whether or not the major developments in the height series were caused by the introduction of general conscription in 1857, we cannot reject the hypothesis that the decline in heights from 1740 to 1820 was due to changing selection. We begin with a consideration of the regional and occupational composition of the sample across all of the various recruitment regimes, move on to statistical tests of overlapping periods, and conclude with an examination of the height series by recruitment period.

Our occupation data tell us something about the socioeconomic composition of the army (even if many of the recruits were too young to know with any certainty how they would earn their living after military service) and therefore of the adult male Portuguese population in general. ${ }^{19}$ We use the Armstrong scheme of five occupational groups, which was designed to classify occupations in nineteenthcentury censuses according to skill level, and differentiate among the four recruitment periods (figure 2). ${ }^{20}$ Each group of bars represents one occupational category, the individual bars within each group standing for each of the four recruitment periods. The first group, for example, represents those recruits whose occupation was recorded as unskilled worker, farmer, or unknown. ${ }^{21}$ The share of recruits in this category during the first three recruitment periods was roughly

\footnotetext{
${ }^{18}$ The sources of our regional-population data are Guardado Moreira and Rodrigues Veiga, 'Evolução', p. 40, and Censo da População de Portugal for the eighteenth and nineteenth centuries, respectively. We have decided not to apply an occupational adjustment, with which we experimented, because the censuses do not provide us with the occupational structure for the eighteenth and early nineteenth century. The best that we could do was to calculate the occupational structure for the conscripts who were examined under the general-conscription law: a sample representative of the entire Portuguese population. Using the data for the first decade (1857-67), we arrived at an occupational structure of $82 \%$ unskilled workers, farmers, and unknown; 3\% semi-skilled workers/ soldiers; $8 \%$ skilled workers; $4 \%$ semi-professional; and (based on regional weighted averages) $4 \%$ professional. Given that the group comprising unskilled workers, farmers, and unknown is our constant and represents such a large percentage of the total, the upward adjustment would never be greater than one millimetre. This is too insignificant to justify the 'cost' in terms of uncertainty about whether a similar occupational structure applied to the eighteenth century. Moreover, this means that we are comparing similar occupational sets, since many of the estimates from the comparison countries (Austria, Russia, the UK, and so on) are also based on samples representing unskilled workers and farmers.

${ }^{19}$ Unfortunately, parental occupations are not available in Portuguese military data.

${ }^{20}$ Armstrong, 'Use of information', pp. 215-23.

${ }^{21}$ The fact that fewer than $5 \%$ of the recruits in this group identified themselves as farmers indicates that farming was not considered a distinct occupation. We have no way of determining how many of those recruits whose occupation was listed as 'unknown' may, in fact, have been farmers. 'Unknown' may have also included some unskilled workers.
} 
PORTUGUESE LIVING STANDARDS

Table 3. Height by birth decade in European regions and real wages in Portugal

\begin{tabular}{|c|c|c|c|c|c|}
\hline Region & Central-west & East & Portugal & South & Portugal \\
\hline Variable & Height & Height & Height & Height & Real wage \\
\hline 1720 & 165.2 & 162.5 & 163.6 & & 0.98 \\
\hline 1730 & 166.0 & 163.3 & 164.3 & & 0.92 \\
\hline 1740 & 167.1 & 166.2 & 164.9 & & 0.91 \\
\hline 1750 & 167.3 & 165.1 & 165.0 & 166.0 & 0.81 \\
\hline 1760 & 168.4 & 164.4 & 165.1 & 166.1 & 0.75 \\
\hline 1770 & 166.8 & 163.0 & 164.4 & 164.7 & 0.71 \\
\hline 1780 & 165.7 & 163.0 & 163.8 & 164.7 & 0.66 \\
\hline 1790 & 165.0 & 161.1 & 163.3 & 166.0 & 0.54 \\
\hline 1800 & 167.1 & 163.0 & 164.3 & 164.5 & 0.46 \\
\hline 1810 & 167.1 & 162.3 & 164.4 & 164.1 & 0.49 \\
\hline 1820 & 165.8 & 163.2 & 164.0 & 165.8 & 0.69 \\
\hline 1830 & 165.9 & 163.6 & 163.6 & 162.6 & 0.55 \\
\hline 1840 & 165.1 & 164.1 & 163.4 & 162.9 & 0.55 \\
\hline 1850 & 165.7 & 163.6 & 163.7 & 162.7 & 0.46 \\
\hline 1860 & 166.6 & 164.3 & 163.6 & 162.9 & 0.46 \\
\hline 1870 & 167.5 & 166.1 & 164.1 & 163.1 & 0.60 \\
\hline 1880 & 168.3 & 167.9 & 163.5 & 163.9 & 0.75 \\
\hline 1890 & 168.8 & 168.3 & 163.7 & 164.4 & 0.62 \\
\hline 1900 & 169.7 & 169.2 & 163.2 & 165.1 & 0.55 \\
\hline 1910 & 170.6 & 169.1 & 164.3 & 165.7 & 0.54 \\
\hline 1920 & 171.0 & 167.0 & 164.9 & 166.5 & \\
\hline 1930 & 173.4 & 167.9 & 165.6 & 166.7 & \\
\hline 1940 & 175.6 & 169.0 & 166.4 & 167.8 & \\
\hline 1950 & 176.5 & 173.7 & 167.4 & 171.1 & \\
\hline 1960 & 178.0 & 175.9 & 169.2 & 173.6 & \\
\hline 1970 & 178.3 & 177.9 & 171.4 & 174.7 & \\
\hline 1980 & 178.9 & 177.0 & 172.1 & 175.0 & \\
\hline
\end{tabular}

Sources: Cols. 1-4: see fig. 4. Col. 5: see fig. 6 and text.

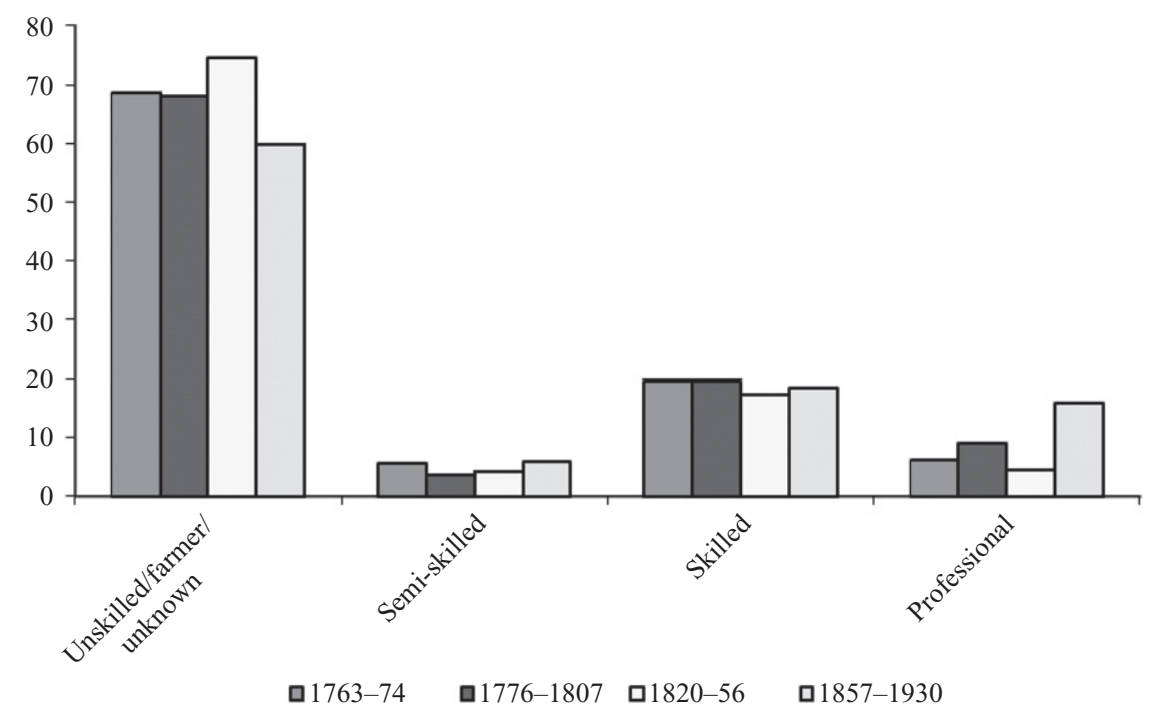

Figure 2. Number of cases by occupational category and recruitment regime Sources: See tab. 1. 
Table 4. Regional shares by recruitment period

\begin{tabular}{lrccccc}
\hline Recruitment period & Alentejo & Algarve & Beira & Estremadura & Minho & Trás-os-Montes \\
\hline 1763-74 & 5.8 & 2.1 & 8.8 & 75.5 & 6.3 & 1.6 \\
$1776-1807$ & 5.9 & 1.3 & 12.9 & 69.8 & 9.5 & 0.6 \\
$1820-56$ & 41.0 & 1.2 & 30.2 & 17.8 & 9.4 & 0.4 \\
$1857-1932$ & 4.6 & 0.9 & 7.3 & 69.9 & 16.8 & 0.6 \\
\hline
\end{tabular}

Sources: See tab. 1

70 per cent (that of the 1820-56 period was slightly higher) and then declined sharply in the last period (1857-1936), by about 10 per cent: a decline that reflects the fact that during the late nineteenth century manufacturing comprised an increasingly large proportion of Portugal's GDP and the fact that skill levels were rising. ${ }^{22}$ During three of the four recruitment periods, the largest percentage of recruits came from Lisbon or elsewhere in the capital's province, Estremadura. The exception was the third period, 1820-56, when a larger percentage came from the adjacent provinces of Alentejo and the Beira (table 4), a regional shift indicating that in order to estimate the general Portuguese height trend one needs to use both regional dummies and regional weighting.

We also determined that differences in the height values of recruits belonging to one and the same 10-year birth cohort recruited under different regimes were insignificant (appendix III). Since the samples for the first two periods were smaller than we would have wished, we checked to see whether there were implausible gaps between one of the resulting height series and the next, and found that all of the important height-trend changes-most notably the eighteenth-century rise and fall, the recovery between the 1790 s and the 1820 s, and then the next decade's stagnation - took place within, rather than between, recruitment periods (figure 3), disproving the hypothesis that the 1740-1820 decline in heights was due to nothing more than changes in recruitment regulations.

Finally, we found that both adjacent and overlapping birth cohorts were quite similar (figure 3). More specifically, the 1780s birth cohort (in the 1776-1807 recruitment period) was similar to the 1790 s birth cohort (in the 1820-56 recruitment period), and the 1830 s birth cohort in the $1820-56$ period was almost identical to the same cohort in the 1857-1932 one. This last observation is key to this article's premise that the height development associated with the 1830s birth cohort was not caused by the introduction of the military draft in 1857 .

Did the size of the army lead to selectivity? When we started this project, we expected that compulsory recruitment was introduced to increase the army size. However, when looking at the true figures for army size, we actually find that it did not change between the mid-eighteenth and the mid- and late nineteenth centuries. Hence our smaller samples of the early cross-sections are not a consequence of army size but of source preservation. We conclude that in this respect there was probably no large bias (see appendix IV).

There were also some interesting regional differences. The south was traditionally the centre of meat and grain production in Portugal, although pigs were more numerous than cattle. The north, in contrast, was more urbanized and agricultural

${ }^{22}$ Lains, Progressos, pp. 249-51. 


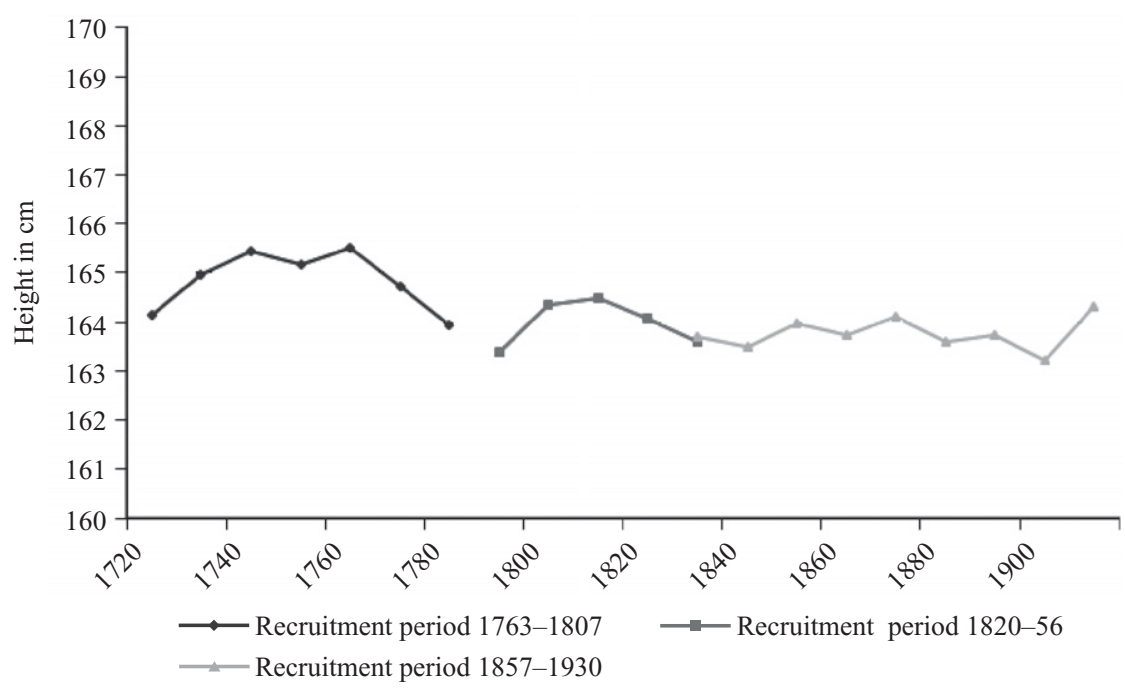

Figure 3. Height development of Portugal, 1720-1910, by recruitment period, regionally adjusted

Sources: See tab. 1.

production included wine among other items. Population densities were higher in the central area and the north, whereas Alentejo and Algarve in the south were less densely populated. Popular images and learned authors are divided between a view of Alentejo as a land of plenty and another as a land of poverty. Recent research by Freire Costa on regional tax receipts shows that revenue per capita in Alentejo was the highest in the country throughout the sixteenth and seventeenth centuries. ${ }^{23}$ This is true of both direct and indirect taxes and suggests a higher per capita income relative to other regions. Traditionally, it also had one of the highest land-labour ratios. In 1820, population density was 10.9 inhabitants per square kilometre, at a time when the national average was 33.9 and the nearest region had a density of 23.7 (Algarve).$^{24}$ This was one of the main reasons for the emphasis on animal husbandry, despite significant production of grain as well, and therefore presumably a high relative consumption of meat. In 1850, grain and meat represented two-thirds of agricultural output and were roughly equivalent. ${ }^{25} \mathrm{~A}$ third element in this picture comes from the second half of the nineteenth century when Alentejo had one of the lowest rates of emigration in the country, usually taken as an indicator of higher income per capita. All this may help explain the initial height differential favourable to Alentejo and similarly Algarve (table 2).

\section{III}

We compare the standard of living in Portugal with the average of a sample of European countries comprising Austria, the UK, France, Germany, Hungary,

\footnotetext{
${ }^{23}$ Freire Costa, 'Hierarquias'.

${ }^{24}$ Matos and Marques, 'Base demográfica'.

${ }^{25}$ Fonseca and Reis, 'Agricultural growth', p. 176. 


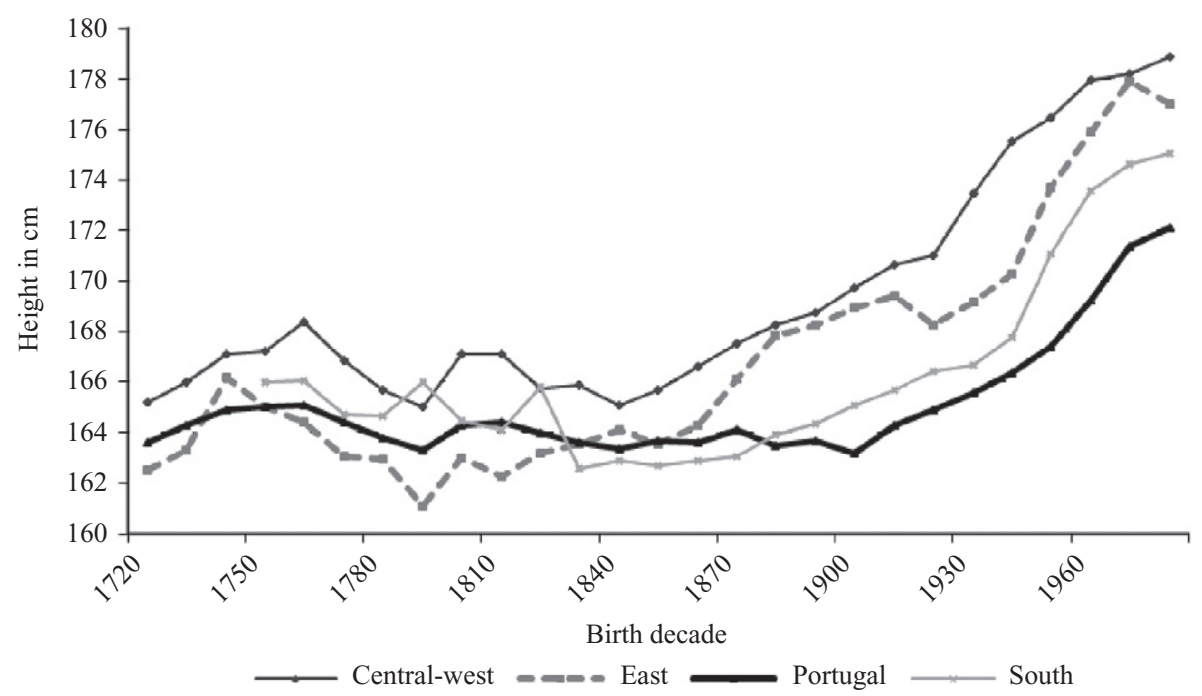

Figure 4. Portuguese versus European heights, 1720-1980

Notes: East: Russia and Hungary. Central-west: Germany, Austria, the Netherlands, the UK, Ireland, France, Sweden. South: Italy and Spain. Eastern Europe in 1720/1730 refers to Russia only. Southern Europe in 1790 and 1800 is Italy only.

Sources: European heights are taken from Baten and Blum, 'Global height trends' (see above, n. 2); Spijker, Pérez, and Cámara, 'Cambios generacionales', p. 597; Martínez-Carrión and Moreno-Lázaro, 'Urban height penalty', p. 160; and a sample for the eighteenth century based on Komlos and Cinnirella, 'European heights', p. 283; A'Hearn, 'Anthropometric evidence', p. 364; Cámara, 'Long-term trends', pp. 66-7; Heintel, Sandberg, and Steckel, 'Swedish historical heights, pp. 454-5; and Cinnirella, 'Optimists', p. 336. Portuguese heights after 1910 are taken from Padez, 'Secular trend', p. 18; and Sobral, 'Secular changes', p. 496.

Italy, Ireland, the Netherlands, Russia, Spain, and Sweden, organized into three groups according to their geographical situation and their height averages: southern Europe (Italy and Spain), central-western Europe (Austria, the UK, France, Germany, Ireland, the Netherlands, and Sweden), and eastern Europe (Hungary and Russia). ${ }^{26}$ Below we will perform panel regressions using the individual countries.

During the first half of the eighteenth century not only was the range of height values among these countries rather narrow (figure 4, values in table 3 ) but Portugal's average was close to theirs. In fact, prior to the 1760 s average height in Portugal increased steadily, by a total of 1.5 centimetres, although this left it somewhere between two and four centimetres behind the central-western group. It then declined until the 1790s, the nadir of the biological standard of living not just in Portugal but in eastern and central-western Europe as well.

The early nineteenth century marked a modest recovery not just in Portugal but also elsewhere in Europe, despite the political chaos and economic dislocation of the Napoleonic era and its aftermath. ${ }^{27}$ Portugal maintained a standard of living somewhere between those of eastern and central-western Europe until the birth

\footnotetext{
${ }^{26}$ Clearly, Ireland was a laggard in this period and it can be discussed whether it should be in this group. However, given its geographic location it belongs to the central-western region. Given that it is only one of six countries, its omission would not change the figures.

${ }^{27}$ The period between the 1790 s and the mid-1810s was the most difficult time for Europeans, both because of the wars and adverse climatic conditions. The last years of the $1810 \mathrm{~s}$ and 1820 s were a relatively peaceful period in Europe on average, and in particular the climatic conditions were very favourable. Hence grain prices during the 1820 s were the lowest of the century until the 'grain invasion' of Europe in the late nineteenth century.
} 
decades of the mid-nineteenth century, the point at which, when it comes to average height, Portugal began to diverge from the rest of Europe, with an alarmingly large proportion of the 1840 s birth cohort measuring under 140 centimetres - a clear sign of severe stunting. Yet for Portugal, as opposed to the rest of Europe, no recovery was in sight.

While central-western and eastern Europe enjoyed a long and steady improvement, Portugal stagnated until the end of the century. By the 1890s it had dropped to last place behind southern Europe, and by the time that the 1910 birth cohort was measured, the gap had increased to a good five centimetres. Portugal had to wait until the second decade of the twentieth century to see a sustained height increase, and even then it was nothing like the European one. Only a modest improvement was achieved, and it was not until the 1950s that socioeconomic change began to have a stronger positive effect on height. ${ }^{28}$ More specifically, both nutrition and the public health system improved between the 1940 s and the 1970s, with the result that during this period life expectancy soared, from just over 50 to 71 years. ${ }^{29}$ Meanwhile, however, the rest of Europe was making the same sort of, and in some cases even greater, progress, with the result that by 1980, instead of seeing their standard of living converge with that of the rest of Europe, the Portuguese found that they were still seven centimetres shorter than the core European populations. Even during the golden age of the 1950 s to the early 1970 s, when it had one of the fastest rates of economic growth in Europe, Portugal was unable to catch up with southern Europe. It is remarkable that in eastern Europe the average of Russia and Hungary performed much better than in both Portugal and the other European countries. Especially after the Russian agricultural reforms of the 1860s eastern Europe did better than southern Europe.

This comparative account of Portugal's long-run anthropometric performance exposes two puzzling phenomena. One is Portugal's lag behind the rest of Europe after about 1850. The other is its distance relative to the rest of southern Europe (Italy and Spain) after about 1890. The next section will try to explain the gap between Portugal and the rest of Europe by focusing on the period before the world wars, ending in 1910, when the gap was at its widest.

\section{IV}

Stature is a function of nutritional quantity and quality, health conditions, and medical care during the early years of life. These components in turn are determined by socioeconomic factors such as income-particularly in the case of the poor-public health, relative prices of protein-rich foodstuffs relative to other goods, and other factors. ${ }^{30}$ Family income, on the one hand, and the cost of health care as well as food and shelter, on the other, during childhood are thus reliable predictors of adult stature. All of these elements are interrelated. For instance, without adequate family income, food containing high-quality protein which is

\footnotetext{
${ }^{28}$ Padez, 'Secular trend', p. 18.

${ }^{29}$ In 1902 a Portuguese newborn's life expectancy was on average 44 years. See da Costa Leite, 'População', p. 59 .

${ }^{30}$ Steckel, 'Stature', p. 1908. 
vital to a child's physical development may be prohibitively expensive. In addition to economic variables, parents' values are responsible for basic human-capital formation, which in turn has an impact on biological well-being.

Since the food, shelter, and other goods that largely determine childhood and adolescent growth are determined by the parents' purchasing power, we begin by looking at the evolution of real wages in our comparison panel of countries. Since real wages are closely correlated with GDP, they are often used, in the absence of other measures, to represent income. ${ }^{31}$ The wages considered, as a rule, are those earned by unskilled labour in a given country's principal city and deflated by local prices. ${ }^{32}$ A recent estimate of long-run GDP per capita for Portugal ${ }^{33}$ treats 50-year intervals, but this is too infrequent for our regressions. We use decadal real-wage estimates instead.

Series for Lisbon real wages (both skilled and unskilled) during the nineteenth century were established some time ago on the basis of data drawn from the accounts of the royal household and charitable institutions in Lisbon. ${ }^{34} \mathrm{~A}$ similar study currently underway extends the series back to the early eighteenth century. It applies Allen's 'welfare ratio' procedure, which calculates the number of basic consumption baskets that a family consisting of two adults and two children could purchase with the yearly income of a male adult labourer working a standard 250 days per year. ${ }^{35}$ This is based on an 'average European' basket created for mideighteenth-century Strasbourg, which we have adjusted to account for variation in diet and in the availability of basic goods. ${ }^{36}$ Our welfare ratio index, based on Lisbon prices and unskilled wages for the period 1720-1910, is in line with what is known about the broad lines of Portugal's economic evolution during this period (figure 5). ${ }^{37}$ If the living standard in the first half of the eighteenth century was stable, it was thanks to a combination of slow population growth, gold and diamond rushes in Minas Gerais, and a thriving plantation economy on the coast

\footnotetext{
${ }^{31}$ Allen, 'Great divergence', p. 413; idem, 'Progress and poverty', p. 406; Williamson, 'Evolution', pp. 142-5.

${ }^{32}$ While a database with a wider geographic scope than that provided by a single city would be more representative of national trends, the use of price and wage data from Lisbon may be justified on several grounds. Portugal is a small country $(89,000$ square $\mathrm{km})$, with Lisbon located roughly at its centre. During the period under study the regional market system was drawn together by its rivers providing access to its seaports. By European standards its markets for basic foodstuffs were quite well integrated in the eighteenth century and even more so in the nineteenth; G. Federico, 'The first European grain invasion: a study in the integration of the European market 1750-1870', European University Institute working paper, HEC no. 2008/01 (2008); Justino, Formação. In addition, qualitative evidence regarding internal labour migration - unrestricted during the period under study - is plentiful; Reis, 'Trabalho', pp. 131-5.

${ }^{33}$ Valério, 'Portuguese economic performance'.

${ }^{34}$ Reis, 'Trabalho', p. 135.

${ }^{35}$ Allen, 'Great divergence', p. 425.

${ }^{36}$ All of the main wage and price series used in this procedure were drawn from market situations and represent actual transactions. They were obtained from the accounts of religious and charitable institutions and the royal palaces. The wage series are derived from the building industry, as is the case in most of the literature, and represent the daily cash remuneration which was the only form of compensation. Prices were observed at different points throughout the year and collected for the following commodities: bread, wine, meat, olive oil, beans, eggs, hens, fuel, and linen cloth. For lack of data, housing is represented by a fixed proportion of total food consumption. In order to render our estimates of Lisbon 'welfare ratios' comparable with those of other European regions, we substituted certain items in the so-called 'Strasbourg consumption basket' (for example, wine and olive oil instead of beer and butter, respectively). The list of sources is too long to include here and the website where it can be found is under construction. The information will soon be published on the PWR (Prices, Wages and Rents in Portugal 1500-1910) website at http://www.ics.ul.pt/instituto/.

37 This analysis of Portugal's long-term economic evolution is based on several chapters in Lains and Ferreira da Silva, História Económica de Portugal (chs. 1-6 in vol. II, and chs. 1-5 in vol. III).
} 


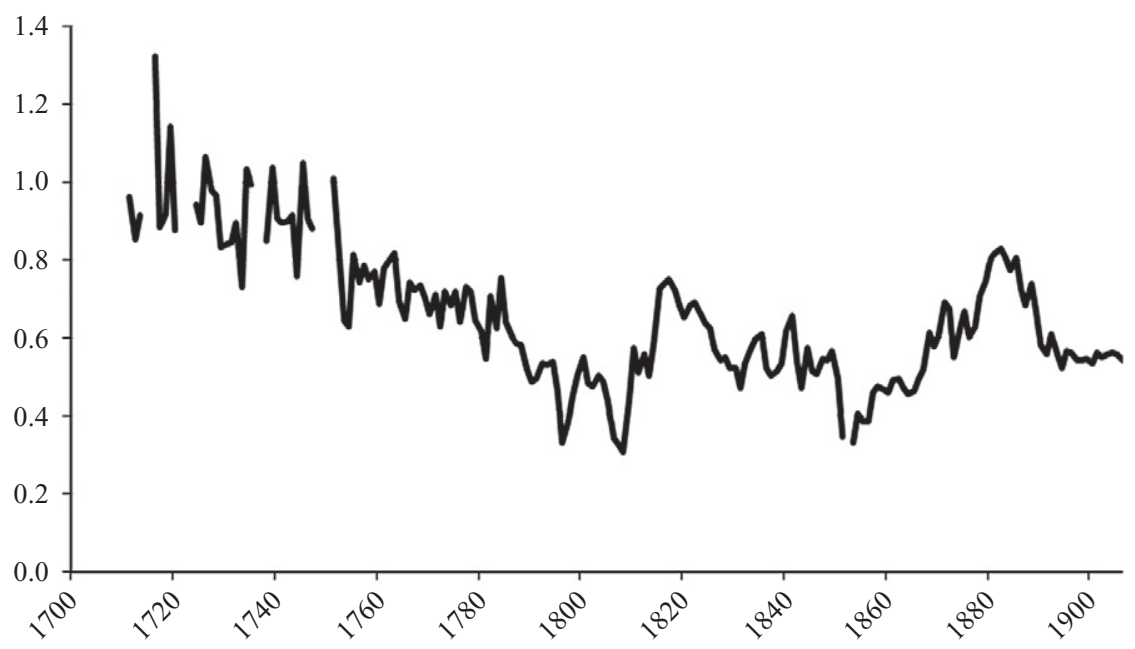

Figure 5. Lisbon real wages ('welfare ratios') in Portugal, 1720-1910

Sources: 'Prices, Wages and Rents in Portugal 1500-1910', project undertaken at the Instituto de Ciências Sociais, Lisbon, in 2009-11, led by J. Reis; and authors' own estimations.

of colonial Brazil. The steady decline in the welfare ratio over the course of the second half of the century was due to a more intense demographic pressure on resources coupled with the exhaustion of the earlier Brazilian boom and a weak productivity response in both the agricultural and manufacturing sectors. During the first two decades of the nineteenth century, the material conditions of the Portuguese recovered to their 1780s level, thanks to the stagnation of the population in tandem with a significant expansion in agricultural production, chiefly that of wine.

However, living conditions during the period from the 1840 s to the 1860 s were driven down to their lowest point since the century began by a series of natural disasters: the bad harvests of the 'Hungry 1840s', the 20-year-long oidium plague that slashed wine production by two-thirds, and a succession of catastrophic floods and coastal storms. ${ }^{38}$ The shock to the agricultural sector, which accounted then for two-thirds of the total labour force, was severe. It was not until the 1870s that wages recovered, driven by a spurt in manufacturing, an increase in emigration to Brazil (yielding considerable home remittances), declining food prices due to grain imports, and a modest expansion in grain, wine, and olive oil production. But the welfare ratio peaked in the 1880s, slipping back in the 1890 s to the level it had been nearly a century earlier. GDP per capita soon experienced a modest upturn, but the welfare ratio missed out on this owing to a decline in labour's share of total income. $^{39}$

The next step is to compare this series with those for the principal cities of the set of countries used above for the height comparison in figure 4. Until the 1740s, Lisbon's real-wage level was among the highest in Europe (figure 6), but in the ensuing 100 years it stagnated and then declined, whereas those of both

\footnotetext{
${ }^{38}$ Joanaz de Melo, 'Contra cheias e tempestades', pp. 77-8.

${ }^{39}$ Reis, 'Trabalho', p. 18. 


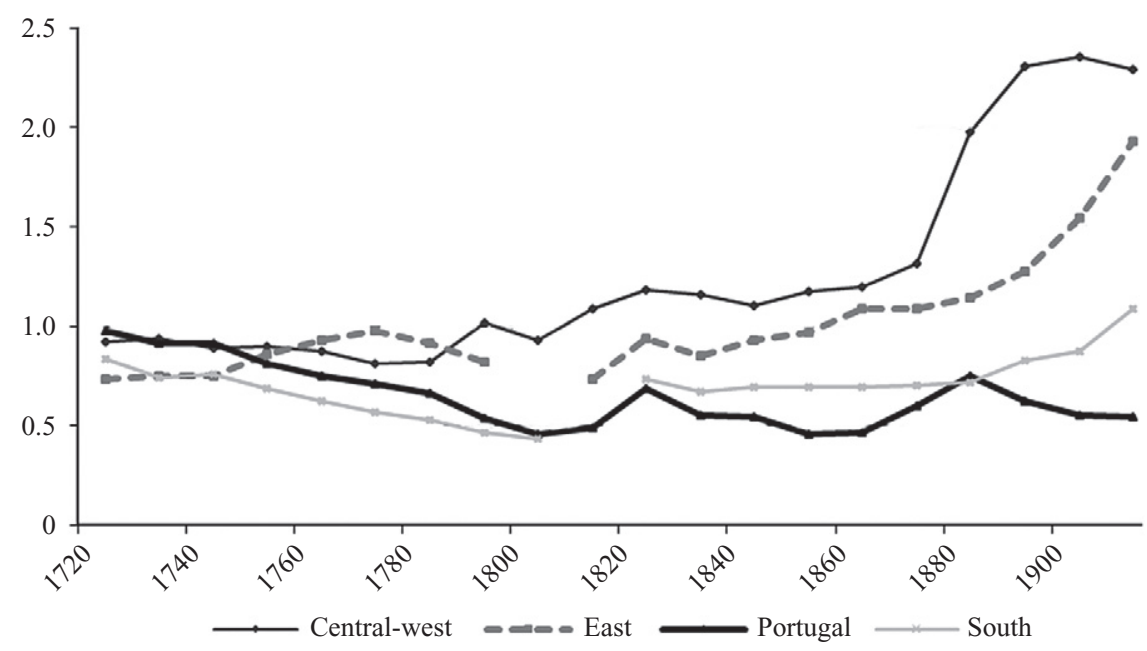

Figure 6. Welfare ratios (= real wages) in European cities

Notes: East: Cracow and Warsaw. Central-west: London, Paris, Strasbourg, Augsburg, and Vienna (after 1880, only London and Paris). South: Madrid and Milan. Lisbon represents Portugal.

Source: Allen, 'Great divergence'.

central-western and eastern Europe soared. By the end of the nineteenth century even those of Milan and Madrid, which had been at the back of the pack prior to the 1790s, were outperforming Lisbon's. It is noteworthy that eastern Europe actually fared better than southern Europe in terms of real wages and corresponds to what we saw above for height differences, especially after the Russian agricultural reforms of the 1860s.

On the face of all this, real wages must be considered a potentially important determinant of heights. Previous studies in other countries, however, have detected important deviations in the relationship between income and height, the bestknown examples being the 'early industrial growth puzzle' in England, and the 'antebellum puzzle' in the US. ${ }^{40}$ In Portugal there are also two observable deviations: the early eighteenth century, when the height increase outpaced that of wages; and a short period in the 1880 s, when the reverse occurred. We therefore consider it necessary to put this hypothesis to the test in our regression analysis below.

Tortella and others have argued that underinvestment in human capital (that is, both education and practical skills) has hampered southern European countries' long-term economic development. ${ }^{41}$ Portugal, with its abysmal literacy and schooling rates, is a case in point. Around 1800, the rate of minimal literacy - that is, the ability to sign one's name-in rural regions was below 20 per cent, and in 1910 the situation was scarcely any better, both literacy and primary-school enrolment rates being among the lowest in Europe. ${ }^{42}$ In the late nineteenth century the low standard of human capital in Portugal provoked frequent complaints on the part of entrepreneurs. ${ }^{43}$ Progress was made in the twentieth century, but, as noted, the

${ }^{40}$ Komlos, 'Shrinking', p. 782; idem, 'Anomalies', pp. 211-12.

${ }^{41}$ Tortella, 'Economic retardation', p. 5.

${ }^{42}$ Reis, 'Economic growth', p. 202.

${ }^{43}$ Reis, 'Human capital and industrialization', p. 31. 
slowness of its evolution goes far towards explaining the fact that the biological standard of living in Portugal has long lagged behind that of other European countries. ${ }^{44}$

Of course, it is beyond the scope of this article to provide a detailed analysis of the causes of this backwardness. One factor might have been the lack of the religious competition which was present in north-western Europe and which might have stimulated education and book production. Undoubtedly, there was never any religious competition in Portugal, a remarkably homogeneous country from this point of view.

Around 1800 in Europe there was a swathe of territory in the north-west which had relatively high literacy rates (the UK, Belgium, Holland, and so on) and where one encounters both the Catholic and Protestant denominations. Baten and van Zanden have argued that religious competition stimulated book consumption and advanced literacy in the early modern period. ${ }^{45}$ One also encounters a strong urban and commercial culture in this region of Europe. Portugal to the south had experienced much less structural change in the meantime. ${ }^{46}$ At the same time, in Portugal the institutional and political impulse for greater provision of schools and elementary education was weak. Little need was felt for an effort by the state to encourage school attendance, particularly by the poorer strata. Two factors were responsible for this. One may have been the weakness of state finances, although the cost of raising literacy would not have been enormous. The other was the fact that the elites in Portugal felt little need for an effort to strengthen, by means of schooling, the allegiance of the mass of the population to the state, the monarchy, and religion, in contrast with similarly poor countries like Greece, Italy, and Spain. The latter developed literacy much more strongly. It is likely that this resulted from the severe threats to the integrity of the state they suffered, as well as to the less intense nationalist sentiments of the population, as witnessed by pronounced linguistic and cultural heterogeneity. ${ }^{47}$ It is interesting to note that obligatory schooling was introduced in Portugal in the 1840s but never seriously implemented. This was a time when it was being effectively introduced throughout the rest of Europe..$^{48}$

Investment in human capital manifests itself in two forms, education and income, both of which affect height trends. Education helps parents, and mothers in particular, to raise the standard of hygiene in their households and to provide their families with a nutritious diet, thereby improving their children's chances of achieving a healthy physical growth rate. On the other hand, parents' income level also determines the quality and quantity of food, shelter, and medical care received by their children. This effect of income will be captured by the real-wage variable in our regressions.

A database for literacy rates compiled for Portugal and the three regions that compose our European sample confirms Portugal's role as the laggard since at

\footnotetext{
${ }^{44}$ Lains, Progressos, pp. 33-57; idem, 'Catching-up', pp. 383-4.

${ }^{45}$ Baten and van Zanden, 'Book production', pp. 230-1.

${ }^{46}$ This paragraph is based on Reis, 'Economic growth', p. 25; J. Reis, C. A. Martins, and L. F. Costa idem, 'New estimates of Portugal's GDP per capita, 1500-1850', paper presented at the Portuguese Economic History Workshop, ICS, University of Lisbon (12 Dec. 2011).

${ }^{47}$ These views are developed in Reis, 'Analfabetismo', pp. 263-9.

${ }^{48}$ See, however, Ramos, 'Culturas da alfabetização', p. 1069.
} 


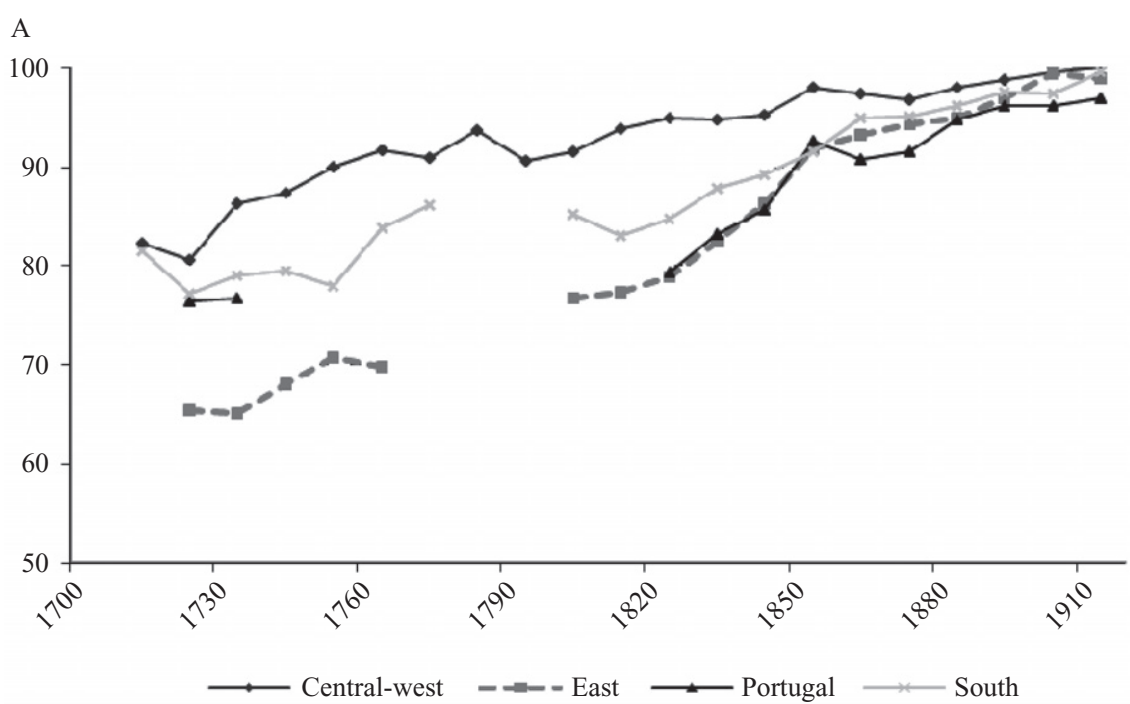

Figure 7. Panel A: Numeracy in Europe, eighteenth to early twentieth century, by birth decade

Sources: Crayen and Baten, 'Global trends', p. 87, fig. 3; A'Hearn et al., 'Quantifying', p. 802, fig. 3; and authors' own calculations. On the eighteenth century: Austria, Germany, Sweden/Denmark, Italy, and Spain: see F. Tollnek and J. Baten, 'The farmer's u: which occupational group inherited human capital in the early modern era?', University of Tuebingen working paper (2009). Italy: the average of north and south Italy was taken. Hungary: J. Baten and R. Benyus, 'Numeracy and Protestantism in Hungary', University of Tuebingen working paper (2009). Russia: J. Baten and M. Szoltysek, 'The human capital of Eastern Europe in global perspective', University of Tuebingen working paper (2011). France: Séguy, La population. Portugal: see text.

least as early as the 1830 s (figure 7 , panel b). ${ }^{49}$ Before this, however, data of this kind do not exist. The only human-capital indicator available for the years prior to the 1830 s is of a far simpler sort than literacy: basic numeracy.

There has been a recent emergence of studies using data in which individuals report their age as an indicator of numeracy levels. ${ }^{50}$ A'Hearn, Baten, and Crayen have shown that in societies characterized by a relatively low level of human capital, the frequency of errors on the part of individuals reporting their age is relatively high. ${ }^{51}$ Their tendency to round off their age to the nearest multiple of five becomes evident in the frequency distribution. The ABCC index, ${ }^{52}$ which provides the percentage of a given population who are numerate - that is, who do not round off-is relevant to our study in that A'Hearn et al. have found a close correlation between this numeracy rate and the literacy rate. This correlation not only remains fairly constant over time but is robust when applied to different types of data as well.

\footnotetext{
${ }^{49}$ Eastern Europe is represented by Russia, Poland, and Hungary; southern Europe by Italy and Spain (as above); and central-western Europe by Austria, the UK, France, Germany, Ireland, the Netherlands, and Sweden.

${ }^{50}$ Mokyr, Ireland, p. 245; Crayen and Baten, 'New evidence', pp. 452-3; A'Hearn, Baten, and Crayen, 'Quantifying', pp. 785-8; Clark, Farewell, pp. 176-7; Cinnirella, 'Optimists', pp. 330-5; Ó Gráda, 'Dublin Jewish demography', p. 129.

${ }^{51}$ A'Hearn et al., 'Quantifying', pp. 799-805.

${ }^{52}$ The abbreviation 'ABCC' is formed from the first letters of the authors' surnames, plus Gregory Clark's, who suggested it in a comment.
} 


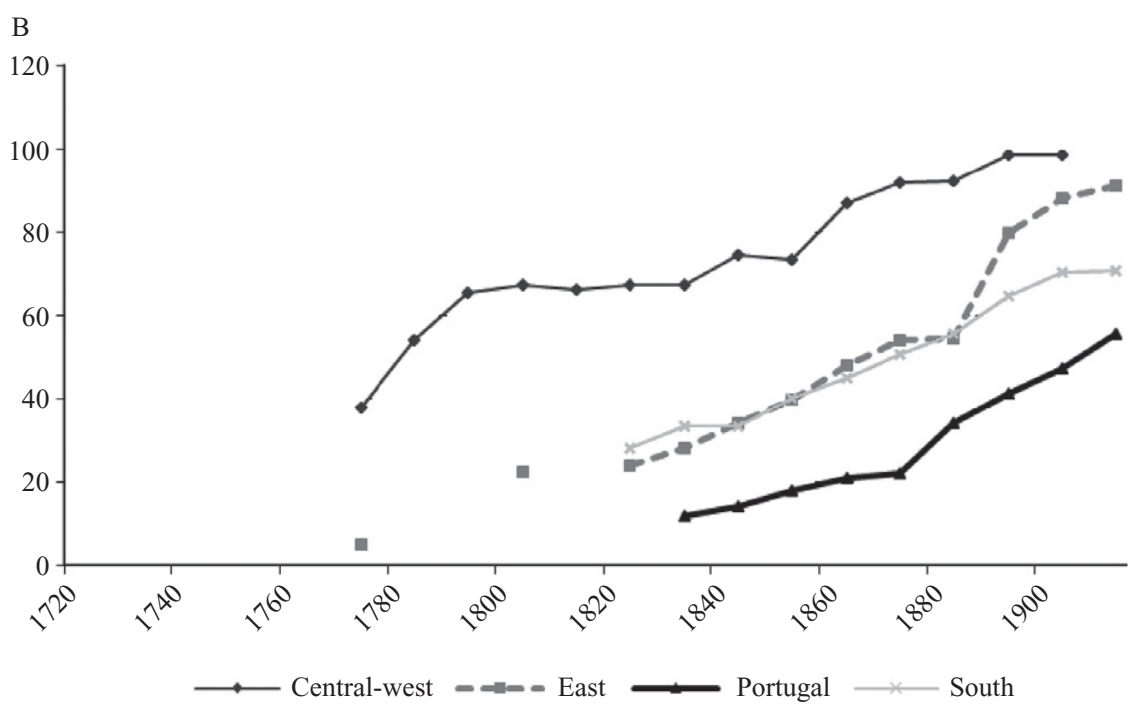

Figure 7. Panel B: Literacy in Europe late eighteenth to early twentieth century, by birth decade

Notes: Central-west: Germany, Austria, the Netherlands, the UK, Ireland, France, Sweden. East: Russia, Poland, and Hungary. South: Italy and Spain.

Sources: Portugal and Spain: Tortella, 'Economic retardation'. Spain: Carreras and Tafunell, Historia económica; Graff, Legacies. Italy: Flora, State. Russia: Mironov, 'Literacy’; Russian Census 1897. Hungary: Tóth, Literacy. Poland: Первая всеобщая перепись населения Российской Империи 1897; United Nations Demographic Yearbook 1963. Austria: Graff, Legacies. Germany: Hofmeister, Prass, and Winnige, 'Elementary education'. France: Gillis, 'Literacy'. Sweden: Johansson, 'History'. Czech and Slovak lands, Germany, Hungary, Ireland, the Netherlands, Poland, Spain, the UK: Flora, State.

Crayen and Baten provide evidence on numeracy in Portugal during the $1870 \mathrm{~s}^{53}$ We have augmented this with the records of 618 individuals who were born between the 1700s and 1730s and were investigated by the Portuguese Inquisition. ${ }^{54}$ Given that the Inquisition especially targeted Jews, whose educational level was, as a rule, above average, one might assume that the numeracy rate in these records would be above average as well, and thus introduce a bias into our calculations. ${ }^{55}$ In fact, this may not be a problem since one-fifth of those in the sample were in more skilled occupations (lawyers, businessmen, and skilled artisans), the remaining 80 per cent consisting of small farmers, unskilled workers, and semi-skilled artisans. Further gaps in the data were closed with Portuguese emigrants to Brazil. ${ }^{56}$ We benchmarked their ABCC on the 1870 s Portuguese national level of non-migrants and only used the change over time in the case of the decades between the 1820s and the 1870 s for which other data were lacking. ${ }^{57}$

How does Portugal's numeracy rate compare with the rates of countries in our European sample? In figure 7, panel a, we present data for Portugal between 1720

\footnotetext{
${ }^{53}$ Crayen and Baten, 'Global trends', p. 85.

${ }^{54}$ We thank Kerstin Manzel and Rose Triebe for providing this evidence, obtained from the register of Inquisition records preserved in the Portuguese national archive (Arquivo Nacional da Torre do Tombo, Lisbon, hereafter ANTT, archival signature codes: PT-TT-TSO/IE, PT-TT-TSO/IL, PT-TT-TSO/IC).

${ }^{55}$ Botticini and Eckstein, 'From farmers to merchants'.

${ }^{56}$ For details, see Stolz, Baten, and Botelho, 'Growth effects'.

${ }^{57}$ During the 1870 s numeracy selectivity among emigrants and stayers was insignificant.
} 
and 1910 , as well as for our three European regions. ${ }^{58}$ In the early eighteenth century Portugal was not far from the more numerate countries in Europe, but by about 1820 it had fallen seriously behind relative to the leading countries. Jointly with eastern Europe, it formed a periphery at this stage. This is an indication that the underinvestment in human capital observed during the early nineteenth century may have contributed to the decline in the numeracy rate and, by extension, to the subsequent decline in both height and income levels. We therefore perform regressions to test the hypothesis of a positive correlation between the ABCC index and average height. In addition, wherever possible, we check numeracy rates against literacy rates as a proxy for human capital.

A variety of historical studies have found a negative effect of urbanization on health trends and thereby on stature in regional cross-sections. ${ }^{59}$ In the largest nineteenth-century cities, this was driven by rampant disease due to severe overcrowding and was aggravated by the absence of proper public health arrangements and an inadequate supply of foodstuffs. Though generally smaller, early modern cities also imposed a high urban penalty on their inhabitants, with life expectation at birth typically between 25 and 30 years. ${ }^{60}$

In the eighteenth century Portugal's urbanization rate, at roughly 15 per cent, was not far from the European mean, and one might reasonably presume that it was not a significant factor in Portugal's height trajectory compared with the rest of Europe during this century. ${ }^{61}$ The same conclusion is not as easy to draw, however, when it comes to the period from 1800 to 1910 . On the one hand, Portugal's cities did not even begin to expand until the 1850s, and then only modestly, so that in 1910 it remained one of the least urbanized countries in Europe. This should have helped narrow the height gap relative to the other countries. On the other hand, a recent study indicates that between 1840 and 1912 the biological standard of living in Lisbon-despite the general perception that the city was profoundly unhealthy - was somewhat superior to that in provincial, mostly rural, Portugal, even after factoring out differences in occupational structures. ${ }^{62}$ This would contradict the beneficial impact of a slow urbanization on the relative height of the Portuguese. The net effect of nineteenth-century urbanization on the biological standard of living is thus left unclear and can therefore only be properly ascertained by controlling for it in our regression analysis below.

Baten has shown that protein supply and protein proximity play important roles in nutritional status. ${ }^{63}$ In pre-industrial societies, purchasing power being equal, nutritional status varied with the quantity of one's livestock, a source of high-quality protein. Cámara uses eighteenth-century Andalusia to show how a breakdown in the supply of high-quality protein could cause a decline in nutritional status.$^{64}$ Did Portugal experience a decrease in livestock production? Direct

\footnotetext{
${ }^{58}$ Eastern Europe is represented here by Hungary and Russia. Throughout the period under consideration southern Europe is represented by Italy and Spain (as before), while central-western Europe comprises Germany, Austria, France, the UK, and Sweden. Ireland could be added for some decades of the mid-to-late nineteenth century, although Ireland was probably slightly less developed during this period.

${ }^{59}$ For a summary, see Komlos and Baten, 'Looking backward', p. 193.

${ }^{60}$ Ibid., p. 193.

${ }^{61}$ Banks, Cross-polity, pp. 55-98.

${ }^{62}$ Reis, "'Urban premium", p. 79.

${ }^{63}$ Baten, 'Protein supply', p. 179.

${ }^{64}$ Cámara, 'Long-term trends', p. 60.
} 
evidence that there was a decline in Portugal's livestock production is limited to the second half of the nineteenth century. Based on several animal censuses, it indicates that from 1852 to 1925 the total number of heads of livestock increased by a respectable 50 per cent. ${ }^{65}$ However, when we factor in a population growth rate of 70 per cent and compositional changes in the stock of animals, what we have, in fact, is an overall decrease in per capita meat consumption of 10 per cent for the entire period and of 16 per cent if the years 1906-25 are excluded. At the same time cereal and potato production kept pace with population growth, thanks to protectionist policies and a decline in the amount of land per capita, which encouraged a shift away from livestock production, causing a decline in nutritional quality, which would have contributed, in turn, to a decline in average height.

This scenario is corroborated by the evolution of the relative price for grain and meat, which rose steadily during the second half of the nineteenth century, indicating that a growing scarcity of animal protein in relation to carbohydrates was indeed being felt at this time. ${ }^{66}$ This implies a substitution in the diet of cereals for meat and a decline in the nutritional status of the population, in particular of the lower strata of society, who would have been more sensitive to these price alterations. It is confirmed by currently available evidence. ${ }^{67}$

In the absence of data, we cannot calculate changes in diet, and by extension in nutrition, during earlier periods. We do know, however, that the market price of meat relative to that of grain steadily declined over the course of the eighteenth century and then, reversing course, increased until the late nineteenth century (figure 8). ${ }^{68}$ To summarize, during roughly the first half of the period under analysis market conditions for nutritional inputs were increasingly favourable and during the second half they were increasingly unfavourable to physical growth.

To assess these findings in a broader context, we have compiled three series of European relative prices of grain and meat. ${ }^{69}$ Two patterns - one involving trends over time, the other price levels - are immediately apparent. First, the four time series move in tandem, declining throughout the eighteenth century and then rising throughout the nineteenth. This is not surprising when one considers the impact on the grain-meat price relationship of two other factors that moved together as well: demography (a proxy for pressure on fixed resources) and real per capita income, an indicator of the intensity of demand for more expensive goods. Second, as far as price levels are concerned, throughout the entire period the price of meat relative to that of grain was lower in Portugal than elsewhere in Europe. This is unexpected, since during the late nineteenth century, and probably earlier as well, its per capita consumption in Portugal was lower. Of course, relative prices are only a part of the story, and one must also take into account disparities in demand driven by per capita

\footnotetext{
${ }^{65}$ Justino, Formação, p. 118.

${ }^{66}$ Reis, 'Crescimento económico', p. 160.

${ }^{67}$ Reis, "“Urban premium"', p. 79.

${ }^{68}$ Milk prices would be a better proxy, but unfortunately they are not available. In the early modern period milk was considered a perishable good that was not taxed as consistently as grain or meat. It perished especially quickly in warm climates. But beef and milk were normally produced by the same farmers, and its relative abundance as indicated by price evidence was correlated. Hence we take relative meat prices as an indicator for relative milk prices. In addition, protein from meat was used as a substitute for milk in many cases.

${ }^{69}$ Once again they represent, respectively, southern Europe (Barcelona and Madrid), central-western Europe (London), and eastern Europe (Krakow and Danzig).
} 


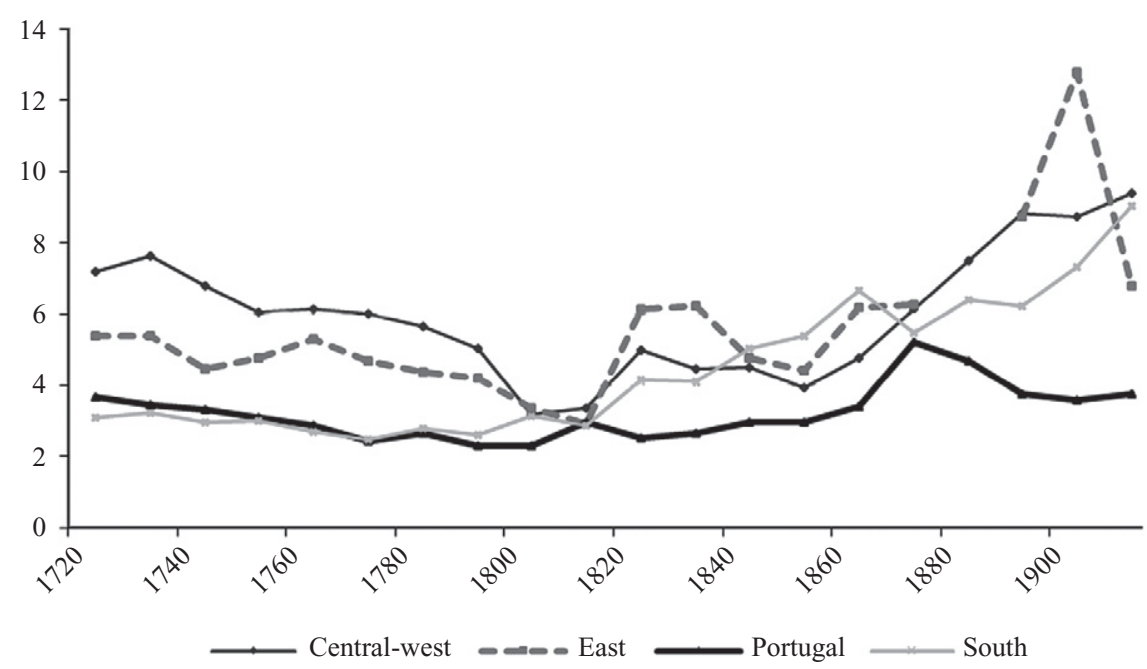

Figure 8. Relative prices of meat and grain for four regions

Notes: Kgs of wheat /rye that can be purchased for the price equivalent of one kg of meat. Southern Europe is represented by a Barcelona series until the first half of the nineteenth century, then by Madrid.

Sources: Picazo, Oligarquía urbana; Nos and Andreu, 'Consumo', p. 22; Martinez Vara, 'Una estimación', p. 103; Feliu, Precios y salaries, pp. 23-9; Nogués Marco, 'Análises', pp. 385-7; Garrabou, Tello, and Roca, 'Preus del blat'; with special thanks to Professor Ramon Ramon, University of Barcelona. Amsterdam represents central-western Europe; J. L. van Zanden, 'The prices of the most important consumer goods, and indices of wages and the cost of living in the western part of the Netherlands, 1450-1800', http://www.iisg.nl/hpw/brenv.xls. An average of Cracow and Danzig stands for the European east; Jacks, 'Intra- and international commodity market', p. 405; idem, 'Market integration', pp. 322-7.

differentials in purchasing power (figure 6). In southern Europe, the choice tended to be a high-quantity (calories) instead of a high-quality (protein) diet. As a result the Portuguese consumed a relatively large quantity of bread and a relatively low quantity of meat, despite the low price of the latter, with potential consequences for their height evolution, which we will test in our econometric section.

Emigration is another factor that can affect anthropometric outcomes. Emigrants sometimes are endowed with above-average height as well as human capital, and their departure can thus reduce the average height level of those who remained behind. Emigration played an important role in Portuguese history, in particular during the late nineteenth and early twentieth century. Hatton and Williamson ${ }^{70}$ report that decadal emigration rates increased substantially, from 1.9 per cent during the 1860 s to a rate of 5 per cent in the first decade of the twentieth century, and then declined. ${ }^{71}$ Portuguese emigration (for which Brazil was the main destination), however, does not seem to have been very selective. Baten, Pelger, and Twrdek found no significant height difference between Portuguese emigrants to Brazil and stayers. ${ }^{72}$ The average height of 1,070 Portuguese male emigrants to Latin America aged between 20 and 54, and born between the 1850s and the 1880s, was 165.1 centimetres, thus less than one centimetre higher than the overall Portuguese average. Additionally, the fact that during this period the average numeracy level of Portuguese emigrants was not significantly different from that of

${ }^{70}$ Hatton and Williamson, Age of mass migration, pp. 10, 180.

${ }^{71}$ Ferenczi and Willcox, International migrations, pp. 89-139, 844-9.

${ }^{72}$ Baten, Pelger, and Twrdek, 'Anthropometric history', p. 327. 




Figure 9. Infant mortality rates

Notes: East: Russia and Poland. Central-west: Austria, France, Germany, the UK, Ireland, Sweden. South: Italy and Spain. Sources: General: Baten and Blum, 'Global height trends' (see above, n. 2), p. 3. Portugal: for 1800, Guardado Moreira and Rodrigues Veiga, 'Evolução'; 1860s evidence is taken from Mapas estatísticos; for 1900, da Costa Leite, 'População'; 1910 is taken from Censo da População no $1^{\circ}$ de faneiro de 1910.

stayers suggests that emigration was not among the factors that explain Portugal's anthropometric divergence from the rest of Europe. ${ }^{73}$

Of course, height trends are also sensitive to the disease environment, since the body uses for growth only those nutrients that remain after it has used the rest for maintenance as well as for recovery from physical exertion. This means that unfavourable disease environments prevent individuals from achieving their full growth potential.

Infant mortality rates are often used as a proxy for ill health during early childhood. Unfortunately, records of the Portuguese infant mortality rate are limited to 1800 , the 1860 s, the 1890 s, and the 1900 s. However, it is safe to say that Portugal's rate was in line with that of countries in our central-western Europe region, which was better than the rates in the other two regions. This variable therefore might not help to explain the Portuguese height divergence from the European core (figure 9).

Typically European governments of the eighteenth and early nineteenth centuries did not introduce social policies in order to maximize the biological standard of living. The focus of their policies was on trade policy, the primary aim being to raise government revenues, mostly through tariffs on luxury goods such as tea and tobacco. $^{74}$

\footnotetext{
${ }^{73}$ There might also be indirect effects of migration. For example, during the late phase of nineteenth-century migration (when most Portuguese emigration occurred), single people and families with few children were over-represented among migrants. The implication of this is that the higher the number of children, the lower the probability of migration. A number of studies have found that a large number of siblings reduces height slightly, because the parents have to distribute resources and attention among more children; Hatton and Martin, 'Effects on stature', pp. 21-2. Ceteris paribus, there might be a small additional influence reducing height.

${ }^{74}$ Only in the event of a harvest failure did grain-exporting countries ever try to restrict food exports. Another major field of government activity was military affairs, the indirect effects of which we have previously discussed. 
In terms of social policy, Lindert has shown ${ }^{75}$ that transfers were meagre prior to the creation of the twentieth-century welfare state-with perhaps one exception: the British poor law, in effect from the 1790 s to the 1830 s. Britain was one of the first states to offer income transfers (outside of the workhouse) for adults who were not physically handicapped but otherwise needy. Since the poor were hit relatively hard by food shortages, such relief may have had a positive impact on average height. On the other hand, a Malthusian would argue that the net effect would be more children born to the poor, who would be blessed with a slightly better survival rate than that of their parents' generation, a combination of changes which could cause average height to decline.

As for Portugal, the only public policy that may have had a positive impact on the biological standard of living was the institution of the foundling hospital, underwritten by local governments and, to a lesser extent, by charitable institutions. In mid-nineteenth-century Portugal 10 per cent of newborns were abandoned, and about half of these died within a few years. ${ }^{76}$ For Europe, this was hardly an exceptional figure and may even have been comparatively low. According to one estimate, the annual abandonment number for the Continent as a whole was 100,$000 ;{ }^{77}$ the French rate was 10 to 20 per cent; ${ }^{78}$ and that of Florence and Milan around $30 .{ }^{79}$

Foundlings are of interest here because they were one of the most disadvantaged groups in society in terms of the link between rearing and physical development. They were brought up, under institutional supervision, by impoverished women with a low human capital endowment, who were not their mothers and did this for purely pecuniary reasons. They were therefore prime candidates for stunting and should have lowered the average height of male cohorts as they emerged into adulthood. On the other hand, the same circumstances were responsible for an exceptionally high fatality rate-anything between 300 and 700 per thousand. This would have raised the cohort's mean stature by virtue of its negative effect on the lower tail of the anthropometric distribution.

In Portugal, the guiding principle on foundlings, as elsewhere, was to minimize expenditure. Consequently, both these outcomes were present. In other words, the parsimony with which they were treated produced a disproportionate share of potentially undersized individuals in the population but also in practice a lesser number of them than if they had been brought up in their original households. As a result, the overall negative impact of the two influences on Portugal's anthropometric profile was likely to be small. Comparatively, the bias thus incurred, if anything, favoured Portuguese heights vis-à-vis those of other countries, given that in the latter, child abandonment occurred on a greater scale.

Since this conclusion leaves the British poor law as the only government policy that could have influenced average height during the period under study, we insert a dummy variable in the regressions below to test for any such effects (UK 1790s-1830s).

\footnotetext{
${ }^{75}$ Lindert, Growing public, p. 39.

${ }^{76}$ ANTT, 'Mapas estatisticos dos baptisados, casamentos e óbitos em cada uma das dioceses do continente do reino. Anno de 1860'.

${ }^{77}$ Kertzer, 'Lives of foundlings', p. 41.

${ }^{78}$ Fuchs, Abandoned children, p. 198.

${ }^{79}$ Kertzer, 'Lives of foundlings', p. 41.
} 
To test our hypotheses, we use a panel data set of 12 European countries including Portugal. ${ }^{80}$ Data for all possible country and decade combinations are not available, but evidence on height, numeracy, and urbanization could be obtained for a respectable sample of 165 country-decade observations. In our panel regressions, height is the dependent variable and lagged human capital, lagged real wages, lagged relative prices for protein, urbanization, and the poor law are the explanatory variables. The lags extend over one decade, in order to avoid contemporaneous correlation. For infant mortality, evidence is available for only a very few benchmark years, but we will include this variable below in an experiment with particularly strong interpolation. ${ }^{81}$ Moreover, our time fixed effects should pick up very serious European-wide health shocks, such as the cholera epidemic during the 1830s. We restrict our analysis to the period 1720-1910, extending it no further because the twentieth-century series are characterized by a great degree of trend correlation. Although modern econometrics would suggest using the longest time series possible, a completely different methodology would need to be applied. Therefore we restricted the sample to 1720-1910 to obtain the longest time frame possible without encountering unit-root problems.

The empirical equation is as follows:

$$
\begin{aligned}
\text { Heights }= & \beta_{1}+\beta_{2} * \text { lagged real wages }+\beta_{3} * \text { lagged human capital }+ \\
& \beta_{4} * \text { lagged relative prices }+\beta_{5} * \text { lagged urbanization }+ \\
& \beta_{6} * \text { poor law }+ \text { time fixed effects }+ \text { regional fixed effects }+\varepsilon
\end{aligned}
$$

We took the logs of the price ratios and of the real-wage variables. For the regressions that included literacy among other explanatory variables, only nineteenth-century values were available. Because basic numeracy and literacy are, as a rule, acquired during the first decade of life, we organized the human-capital variable by birth decade, but then we lagged it also by one decade to make sure that the explanatory values precede the values of the dependent variable. All estimations were weighted by the square root of population size of the respective countries (except the one in column 7 of table 5) and we report robust $p$-values to avoid heteroskedasticity problems. ${ }^{82}$

Which effects would we expect? As the price of meat increases, so does that of protein, and heights might decline ceteris paribus. We therefore expect the relative price of meat to show a negative sign. On the other hand, both real wages and human capital should have a positive effect on heights, infant mortality a negative one, whereas those of the poor law, and perhaps also of the urban-share effects, are less clear.

We regressed heights on the human-capital proxies while controlling for time effects with birth-decade dummy variables (table 5, column 1-4). Both numeracy (column 1-3) and literacy (in column 4) have a significant impact on our dependent variable (table 5). In column 2, we estimated with country fixed effects in order to control for unobserved country-specific heterogeneity. Even under this relatively tough test, the influence of numeracy remained significant.

\footnotetext{
${ }^{80}$ Apart from the countries mentioned above we also included Bohemia, today's Czech Republic, in some of the regressions.

${ }^{81}$ We thank an anonymous referee for this suggestion.

${ }^{82}$ Maddison, World economy, app. B.
} 
Table 5. Unbalanced panel regressions of height in European countries, 1720-1910, on lagged human capital and other variables

\begin{tabular}{|c|c|c|c|c|c|c|c|}
\hline & (1) & (2) & (3) & (4) & (5) & (6) & (7) \\
\hline Numeracy & $\begin{array}{l}14.38^{* * * *} \\
(0.008)\end{array}$ & $\begin{array}{l}6.733 * * \\
(0.020)\end{array}$ & $\begin{array}{c}10.71^{*} \\
(0.068)\end{array}$ & & $\begin{array}{l}9.217^{* * * *} \\
(0.001)\end{array}$ & $\begin{array}{c}11.70 * * \\
(0.029)\end{array}$ & $\begin{array}{l}14.10 * * * \\
(0.009)\end{array}$ \\
\hline Literacy & & & & $\begin{array}{l}6.379 * * * \\
(0.000)\end{array}$ & & & \\
\hline Real wages $(\log )$ & $\begin{array}{c}0.829 * \\
(0.087)\end{array}$ & & $\begin{array}{l}1.891 * * * \\
(0.000)\end{array}$ & & & $\begin{array}{r}1.467 * * * \\
(0.00311)\end{array}$ & $\begin{array}{c}0.865^{*} \\
(0.0658)\end{array}$ \\
\hline Urbanization (log) & $\begin{array}{l}1.676^{* * * *} \\
(0.004)\end{array}$ & $\begin{array}{c}0.970 \\
(0.199)\end{array}$ & & & & $\begin{array}{l}2.020 \text { *** } \\
(0.000)\end{array}$ & $\begin{array}{l}1.980 * * * \\
(0.000)\end{array}$ \\
\hline Poor law & $\begin{array}{l}2.036^{* * *} \\
(0.044)\end{array}$ & $\begin{array}{l}2.577^{* * * *} \\
(0.002)\end{array}$ & & $\begin{array}{l}2.437 * * * \\
(0.001)\end{array}$ & $\begin{array}{l}3.159 * * \\
(0.012)\end{array}$ & & \\
\hline Relative price of protein (log) & & & & & $\begin{array}{c}0.298 \\
(0.813)\end{array}$ & & \\
\hline Infant mortality & & & & & & $\begin{array}{c}0.00867 \\
(0.109)\end{array}$ & \\
\hline Tim & Yes & Ye & $\mathrm{Ye}$ & $\mathrm{Ye}$ & $\mathrm{Ye}$ & Yes & Yes \\
\hline Country fixed effects & No & Yes & $\mathrm{N}$ & $\mathrm{N}$ & $\mathrm{N}$ & No & No \\
\hline Weighted & Yes & $\mathrm{Y}$ & Yes & Yes & Yes & Yes & No \\
\hline Constant & $\begin{array}{r}146.9^{* * * *} \\
(0.000)\end{array}$ & $\begin{array}{r}159.5 * * * \\
(0.000)\end{array}$ & $\begin{array}{r}156.3 * * * \\
(0.000)\end{array}$ & $\begin{array}{r}163.2^{* * * *} \\
(0.000)\end{array}$ & $\begin{array}{r}159.7 * * * * \\
(0.000)\end{array}$ & $\begin{array}{r}146.8^{* * * *} \\
(0.000)\end{array}$ & $\begin{array}{r}145.9^{* * * *} \\
(0.000)\end{array}$ \\
\hline & 79 & 165 & 79 & 134 & 157 & 79 & 79 \\
\hline Adjusted $\mathrm{R}^{2}$ & 0.614 & 0.745 & 0.522 & 0.606 & 0.583 & 0.600 & 0.579 \\
\hline
\end{tabular}

Notes: Robust $p$-values in parentheses. $* * * p<0.01, * * p<0.05, * p<0.1$. Estimations are weighted by square root of population of countries. Numeracy and literacy values are expressed between 0 and 1 . Urbanization and infant mortality are linearly interpolated where values were missing. Residuals are stationary. (Fisher-test $p$-value between 0.000 and 0.001 for the specifications $1-5$ and $7, \mathrm{H} 0$ of a unit root can be rejected. Only for experimental specification 6 with its strongly interpolated infant mortality rates, residuals were not stationary). The relative price of protein was available only at a regional level of aggregation, not at a country level (hence regression 5 is estimated with clustered standard errors on the regional level). The four regions are Portugal, eastern Europe, central-west, and south.

For log urbanization, we used Malanima's urbanization rates of 5,000 inhabitants and above; Malanima, 'Urbanization'.

Descriptive statistics (mean, standard deviation in brackets): height 165.87 (2.678), lagged numeracy $0.906(0.111)$, lagged literacy $0.607(0.249)$, lagged log real wage -0.216 (0.461), lagged urbanization $2.306(0.790)$, poor law $0.017(0.131)$, lagged $\log$ infant mortality rate $186.099(57.173)$, lagged log relative price of protein $1.620(0.366)$.

Real wages are positive and statistically significant in a number of different specifications. We should mention that the inclusion of this variable excludes Russia, Bohemia, and Hungary from the sample because no welfare ratios have yet been estimated for those countries. This reduces the sample size substantially if real wages are included; estimation becomes less precise. For example, after the inclusion of both real wages and country fixed effects, regressions would not render sensible results due to a small number of cases.

When urbanization and a dummy variable for the British poor law are included, both turn out positive and sometimes significant. The negative effects of urbanization might have outperformed the positive ones, and the same might be true of the poor law effects.

When we control for country and time-fixed effects, the results are robust: that is, both the range in magnitude of the human capital coefficient and the significance levels remain unchanged (table 5, column 2). The adjusted $\mathrm{R}^{2}$ is satisfactory for all specifications. Moreover, we introduced a robustness check by not including the Portuguese eighteenth-century values based on the Inquisition source in the final regression and the results did not change. ${ }^{83}$

\footnotetext{
${ }^{83}$ Not shown here, available from the authors. 
Our next step was to examine the effect of the relative price of meat on height (table 5, column 5). ${ }^{84}$ As we could estimate this variable only for the aggregation level of European regions, we used clustered standard errors. The sign is positive, but insignificant, possibly because in economies such as those of our eastern regions, with low market integration, it was milk, rather than meat, that was the chief source of protein.

We also ran an experiment by using infant mortality with quite strong assumptions: we backpolated based on the first available value, and interpolated between benchmarks. ${ }^{85}$ The result is an insignificant coefficient. The aim of this exercise was not to assess the role of the disease environment per se, but to check whether such a very rough estimate of infant mortality might, for example, change the human capital coefficient. This coefficient of core interest here did not lose its significance.

Finally, while we usually weighted all regressions with the square root of population size, in column 7 we removed this weighting to determine if the results would change if all 12 countries had the same weight. The results did not change much.

The descriptive statistics of means and standard deviations are reported in the notes below the table. A standard technique for determining the economic significance of such coefficients is to multiply those of the explanatory variables by their respective standard deviations. This allows us, for example, to compare the outcomes of average and high values of the explanatory variable. Thus if we multiply one standard deviation of numeracy (expressed between 1 and 0 , as in table 5), which is 0.11 , by the numeracy coefficient of 14.38 in model 1 , we get 1.6 centimetres. In other words, the model predicts that if numeracy were to rise by one standard deviation, the difference in anthropometrically measured welfare would be expressed by a change in height of 1.6 centimetres, an increase regarded in most of the literature as a substantial one. If we perform the same calculation with literacy (column 4, standard deviation $=0.249$ ), the height increase would be 1.7 centimetres; with real wages - following the result of column 3-an increment of one standard deviation (0.461) would result in a height increase of 0.9 centimetres, although other coefficients of real wages were admittedly smaller.

\section{VI}

As recently as the year 2000, and despite decades of economic development, the Portuguese remained shorter than any other European nationality. ${ }^{86}$ The aim of this article was to determine whether they always held this record, and if not, then to determine both when and why there was a change in their average height. What we found is that in the early eighteenth century the average height of the Portuguese was

\footnotetext{
${ }^{84}$ The cattle per capita variable proved to be insignificant, possibly because the productivity rate varied among regions.

${ }_{85}$ We thank an anonymous referee for this idea.

${ }^{86}$ However, on the anthropometric situation today we need to add a note of caution. The Portuguese are still the shortest Europeans, but they have not been the poorest Europeans over the last few decades. For example, Moldavians and Romanians have at present a lower GDP per capita. Now, at the high relative income levels achieved by most OECD countries, nutritional behaviour independent of income scarcities becomes more important; Baten and Blum, 'Global height trends' (see above, n. 2), p. 21. We think that a path dependency of nutritional behaviour could be a possible reason why the Portuguese are still the shortest today, though not the poorest, as a result of the economic forces of the nineteenth and early twentieth century, without which the phenomenon cannot be understood.
} 
on a par with that of other Europeans; that it began to diverge in the 1840s; that the divergence increased significantly during the 1870s; and that since 1890 they have been firmly positioned in last place. We scrutinized the determinants of Portugal's tardy height development by focusing on the period when the gap widened. OLS regression results suggest that a modest real wage evolution, as a result of Portugal's comparatively late industrialization and slow economic growth performance, was one determinant. The British poor law and urban development had a positive effect in the regression. How does the urbanization result square with the urban penalty argument that cities are unhealthy and decrease average height? In fact, in most comparisons of industrialized cities and rural places this negative result was obtained. However, this was typically a cross-sectional result within a single country. It is less clear whether more urbanized and developed countries had lower average heights. Our finding suggests the opposite.

Relative prices of protein and disease environment did not have a statistically significant impact. On the other hand, we find delayed human capital formation to have been clearly of importance. Investment in human capital had a substantial impact, and given that the path dependency of educational choices implies that human capital tends to recreate itself, the effects were long-run in nature. The history of European welfare development can only be understood by taking into account those educational investments.

$\begin{array}{ll}\text { Date submitted } & 23 \text { May } 2011 \\ \text { Revised version submitted } & 7 \text { November } 2011 \\ \text { Accepted } & 28 \text { December } 2011\end{array}$

DOI: $10.1111 / \mathrm{j} .1468-0289.2012 .00658 . x$

\section{Footnote references}

A'Hearn, B., 'Anthropometric evidence on living standards in northern Italy, 1730-1860', fournal of Economic History, 63 (2003), pp. 351-81.

A'Hearn, B., Baten, J., and Crayen, D., 'Quantifying quantitative literacy: age heaping and the history of human capital', Fournal of Economic History, 69 (2009), pp. 783-808.

Allen, R. C., 'The great divergence in European wages and prices from the middle ages to the First World War', Explorations in Economic History, 38 (2001), pp. 411-47.

Allen, R. C., 'Progress and poverty in early modern Europe', Economic History Review, LVI (2003), pp. 403-43.

Armstrong, W. A., 'The use of information about occupation', in E. A. Wrigley, ed., Nineteenth-century society: essays in the use of quantitative methods for the study of social data (Cambridge, 1972), pp. 191-310.

Banks, A. S., Cross-polity time-series data (Cambridge, Mass., 1971).

Baten, J., 'Protein supply and nutritional status in nineteenth century Bavaria, Prussia and France', Economics and Human Biology, 7 (2009), pp. 165-80.

Baten, J., Pelger, I., and Twrdek, L., 'The anthropometric history of Argentina, Brazil and Peru during the 19th and early 20th century', Economics and Human Biology, 7 (2009), pp. 319-33.

Baten, J. and van Zanden, J. L., 'Book production and the onset of early modern growth', fournal of Economic Growth, 13 (2008), pp. 217-35.

Botticini, M. and Eckstein, Z., 'From farmers to merchants, conversions and diaspora: human capital and Jewish history', Fournal of the European Economic Association, 5 (2007), pp. 885-926.

Cámara, A. D., 'Long-term trends in height in rural eastern Andalusia (1750-1950)', Historia Agraria, 47 (2009), pp. 47-67.

Carreras, A. and Tafunell, X., Historia económica de la España contemporánea (Barcelona, 2004).

Cinnirella, F., 'Optimists or pessimists? A reconsideration of nutritional status in Britain, 1740-1856', European Review of Economic History, 12 (2008), pp. 325-54.

Clark, G., A farewell to alms. A brief economic history of the world (Princeton, NJ and Oxford, 2007).

Crayen, D. and Baten, J., 'Global trends in numeracy 1820-1949 and its implications for long-run growth', Explorations in Economic History, 47 (2010), pp. 82-99. 
Crayen, D. and Baten, J., 'New evidence and new methods to measure human capital inequality before and during the industrial revolution: France and the US in the seventeenth to nineteenth centuries', Economic History Review, 63 (2010), pp. 452-78.

da Costa Leite, J., 'População e crescimento económico', in P. Lains and Á. Ferreira da Silva, eds., História económica de Portugal 1700-2000, II: O século XIX (Lisbon, 2005), pp. 43-81.

da Silva Lopes, J. B., Memoria sobre a reforma dos pezos e medidas em Portugal segundo o sistema métrico-decimal (Lisbon, 1849).

Diário da Câmara dos Srs. Deputados da Nação Portuguesa (Lisbon, 1823).

Dores Costa, F., Insubmissão. Aversão ao serviço militar no Portugal do século XVIII (Lisbon, 2010).

Feliu, G., Precios y salarios en la Cataluña moderna, 2 vols. (Madrid, 1991).

Ferenczi, I. and Willcox, W. F., International migrations, vols. I-II (New York, 1929).

Flora, P., State, economy and society in western Europe: 1815-1975. A data handbook in two volumes, 2 vols. (Frankfurt, 1982).

Fonseca, H. and Reis, J., 'The limits of agricultural growth in a fragile eco-system: total factor productivity in Alentejo, 1750-1850', in M. Olsson and P. Svensson, eds., Growth and stagnation in European historical agriculture (Turnhout, 2011), pp. 167-94.

Frank, Z., 'Stature in nineteenth-century Rio de Janeiro: preliminary evidence from prison records', fournal of Iberian and Latin American History, 24 (2006), pp. 465-89.

Freire Costa, L., 'Hierarquias regionais e fiscalidade: o Algarve na zona sul do reino (1527-1680)', in Á. Garrido, L. Freire Costa, and M. Duarte, eds., Economia, administração e império. Estudos em homenagem a foaquim Romero Magalhães (Coimbra, 2012).

Fuchs, R. G., Abandoned children: foundlings and child welfare in nineteenth-century France (Albany, NY, 1984).

Garrabou, R., Tello, E., and Roca, A., 'Preus del blat i salaris agrícoles a Catalunya (1720-1936)', in A. Carreras and M. Gutiérrez, eds., La industrialització $i$ el desenvolupament econòmic d'Espanya (Barcelona, 1999), pp. 422-60.

Gillis, A. R., 'Literacy and the civilization of violence in 19-century France', Sociological Forum, 9 (1994), pp. 371-401.

Graff, H. J., The legacies of literacy. Continuities and contradictions in western culture and society (Bloomington, Ind., 1987).

Guardado Moreira, M. J. and Rodrigues Veiga, T., 'A evolução da população', in P. Lains and Á. Ferreira da Silva, eds., História económica de Portugal, 1700-2000, I: O século XVIII (Lisbon, 2005), pp. 35-65.

Hatton, T. J. and Martin, R. M., 'The effects on stature of poverty, family size, and birth order: British children in the 1930s', Oxford Economic Papers, 62 (2010), pp. 157-84.

Hatton, T. J. and Williamson, J. G., The age of mass migration: causes and economic impact (Oxford, 1998).

Heintel, M., Sandberg, L. G., and Steckel, R. H., 'Swedish historical heights revisited: new estimation techniques and results', in J. Komlos and J. Baten, eds., The biological standard of living in comparative perspective (Stuttgart, 1998), pp. 449-58.

Hofmeister, A., Prass, R., and Winnige, N., 'Elementary education, schools, and the demands of everyday life: northwest Germany in 1800', Central European History, 31 (1998), pp. 329-84.

Hueso, A. D. C., 'Fuentes antropométricas en España: problemas metodológicos para los siglos XVIII y XIX', Historia Agraria, 38 (2006), pp. 105-18.

Jacks, D. S., 'Market integration in the North and Baltic Seas, 1500-1800', Fournal of European Economic History, 33 (2004), pp. 285-329.

Jacks, D. S., 'Intra- and international commodity market integration in the Atlantic economy, 1800-1913', Explorations in Economic History, 42 (2005), pp. 381-413.

Joanaz de Melo, C., 'Contra cheias e tempestades: consciência do território, debate parlamentar e políticas de Águas e de Florestas em Portugal, 1852-1886' (unpub. Ph.D. thesis, European Univ. Institute, Florence, 2010).

Johansson, E., 'The history of literacy in Sweden', in H. J. Graff, ed., Literacy and social development in the west: a reader (Cambridge, 1981), pp. 151-82.

Justino, D., A formação do espaço económico nacional: Portugal, 1810-1913 (Lisbon, 1988).

Kertzer, D. I., 'The lives of foundlings in nineteenth-century Italy', in C. Panther-Brick and M. T. Smith, eds., Abandoned children (Cambridge, 2000), pp. 41-56.

Komlos, J., 'Anomalies in economic history: toward a resolution of the "Antebellum Puzzle", fournal of Economic History, 56 (1996), pp. 202-14.

Komlos, J., 'Shrinking in a growing economy? The mystery of physical stature during the industrial revolution', Fournal of Economic History, 58 (1998), pp. 779-802.

Komlos, J. and Baten, J., 'Looking backward and looking forward: anthropometric research and the development of social science history', Social Science History, 28 (2004), pp. 191-210.

Komlos, J. and Cinnirella, F., 'European heights in the early 18th century', Vierteljahrschrift für Sozial- und Wirtschaftsgeschichte, 94 (2007), pp. 271-84.

Lains, P., 'Catching-up to the European core: Portuguese economic growth, 1910-1990', Explorations in Economic History, 40 (2003), pp. 369-86.

Lains, P., Os progressos do atraso: uma nova história económica de Portugal, 1842-1992 (Lisbon, 2003).

Lains, P. and Ferreira da Silva, Á., eds., História económica de Portugal. 1700-2000, 3 vols. (Lisbon, 2005). 
Lindert, P., Growing public. Social spending and economic growth since the eighteenth century, 1: The story (Cambridge, 2004).

Maddison, A., The world economy: a millennial perspective (Paris, 2001).

Malanima, P., 'Urbanization', in S. Broadberry and K. H. O'Rourke, eds., The Cambridge economic history of modern Europe, I: 1700-1870 (Cambridge, 2010), pp. 235-63.

Martínez-Carrión, J.-M. and Moreno-Lázaro, J., 'Was there an urban height penalty in Spain, 1840-1913?', Economics and Human Biology, 5 (2007), pp. 144-64.

Martinez Vara, T., 'Una estimación del coste de la vida en Santander, 1800-1860', Revista de Historia Económica, 15 (1997), pp. 87-124.

Matos, P. L. and Marques, A. H. O., 'A base demográfica', in A. H. O. Marques, ed., Nova história de Portugal, IX: Portugal e a Instauração do Liberalismo (Lisbon, 2002), pp. 13-45.

Mironov, B. N., 'The development of literacy in Russia and the USSR from the tenth to the twentieth centuries', History of Education Quarterly, 31 (1991), pp. 229-52.

Mokyr, J., Why Ireland starved. A quantitative and analytical history of the Irish economy 1800-1850 (1983).

Nogués Marco, P., 'Análises de la deflación española de la primera mitad del siglo XIX: una comparación international', Revista de Historia Económica Año XXIII, 2 (2005), pp. 371-405.

Nos, R. N. and Andreu, J. P., 'El consumo de proteínas animales en Barcelona entre las décadas de 1830 y 1930 : evolución y factores condicionantes', Investigaciones de Historia Económica, 3 (2005), pp. 101-34.

Ó Gráda, C., 'Dublin Jewish demography a century ago', Economic and Social Review, 37 (2006), pp. $123-47$.

Padez, C., 'Secular trend in Portugal', Fournal of Human Ecology, 22 (2007), pp. 15-22.

Padez, C. and Johnston, F., 'Secular trends in male adult height 1904-1996 in relation to place of residence and parent's educational level in Portugal', Annals of Human Biology, 26 (1999), pp. 287-98.

Pereira Marques, F., Exército, mudança e modernização na primeira metade do século XIX (Lisbon, 1999).

Picazo, M. T. P., Oligarquía urbana y campesinado en Murcia 1875-1902 (Murcia, 1986).

Ramos, R., 'Culturas da alfabetização e culturas do analfabetismo em Portugal: uma introdução à história da alfabetização no Portugal contemporâneo’, Análise Social, XXIV, 103/4 (1988), pp. 1067-145.

Reis, J., 'El analfabetismo en Portugal en el siglo XIX: una interpretacion', in C. E. Núñez and G. Tortella, eds., La maldicion divina: ignorancia y atraso económico en perspectiva histórica (Madrid, 1993), pp. 237-70.

Reis, J., 'Crescimento económico e estatura humana. Há um paradoxo antropométrico em Portugal no século XIX?', Memórias da Academia das Ciências de Lisboa, Classe de Letras, XXXV (2002/3), pp. 153-69.

Reis, J., 'Human capital and industrialization: the case of a late comer-Portugal, 1890', in J. Ljungberg and J.-P. Smits, eds., Technology and human capital in historical perspective (Basingstoke, 2004), pp. 22-48.

Reis, J., 'Economic growth, human capital formation and consumption in western Europe before 1800', in R. C. Allen, T. Bengtsson, and M. Dribe, eds., Living standards in the past. New perspectives on well-being in Asia and Europe (Oxford, 2005), pp. 195-226.

Reis, J., 'O trabalho', in P. Lains and Á. Ferreira da Silva, eds., História económica de Portugal, 1700-2000, II: O século XIX (Lisbon, 2005), pp. 119-51.

Reis, J., “Urban premium” or "urban penalty"? The case of Lisbon, 1840-1912', Historia Agraria, 47 (2009), pp. 69-94.

Séguy, I., La population de la France de 1670 à 1829-l'enquête Henry et ses données (Paris, 2001).

Selvagem, C., Portugal militar. Compêndio de história militar e naval de Portugal. Desde as origens do estado portucalense até ao fim da Dinastía de Bragança, supplement edn. (Lisbon, 1931).

Silva, M. B., 'Las dimensiones urbanas. Los patrones coloniales y decimonónicos', in Conference Presentation, 49 Congreso Internacional de Americanistas. Quito, fulio de 1997 (1997) http://www.naya.org.ar/congresos/contenido/ 49CAI/Silva.htm (accessed on 20 Feb. 2012).

Sobral, F., 'Secular changes in stature in southern Portugal between 1930 and 1980 according to conscript data', Human Biology, 62 (1990), pp. 491-504.

Spijker, J. J. A., Pérez, J., and Cámara, A. D., 'Cambios generacionales de la estatura en la España del siglo XX a partir de la Encuesta Nacional de Salud', Revista Estadística Española, 169 (2008), pp. 571-604.

Steckel, R. H., 'Stature and the standard of living', Fournal of Economic Literature, XXXIII (1995), pp. $1903-40$.

Stolz, Y., Baten, J., and Botelho, T., 'Growth effects of 19th century mass migrations: “fome zero" for Brazil?', European Review of Economic History (forthcoming).

Tortella, G., 'Patterns of economic retardation and recovery in south-western Europe in the nineteenth and twentieth centuries', Economic History Review, XLVII (1994), pp. 1-21.

Tóth, I. G., Literacy and written culture in early modern central Europe (Budapest, 2000).

Valério, N., 'Portuguese economic performance, 1250-2000', in J. H. Andreu, J. L. Garcia Ruiz, J. M. Critz, and J. M. Ortiz-Villajos, eds., Las Claves del Desarrollo Economico. Ensayos en Homenaje al Professor Gabriel Tortella (Madrid, 2010), pp. 431-44.

Williamson, J. G., 'The evolution of global labor markets since 1830: background evidence and hypotheses', Explorations in Economic History, 32 (1995), pp. 141-96.

\section{Official publication}

Mapas estatísticos dos baptismos, casamentos e óbitos que houve no reino durante o ano de 1862 (Lisbon, 1869). 
Censo da População de Portugal (Lisbon, 1890) http://censos.ine.pt/xportal/xmain?xpid=INE\&xpgid=censos_ historia_pt_1890 (accessed on 2 May 2012).

Censo da População no $1^{\circ}$ de Faneiro de 1910 (Lisbon, 1913).

United Nations Demographic Yearbook 1963 (1964) http:/unstats.un.org/unsd/demographic/products/dyb/dybsets/ 1963\%20DYB.pdf (accessed on 2 May 2012).

Первая всеобщая перепись населения Российской Империи 1897 г. Распределение населения по родному языку и регионам [First General Russian Empire Census of 1897] (St Petersburg, 1897).

\section{APPENDIX I: IN WHICH UNITS WAS HEIGHT MEASURED?}

The official conversion rate of the Portuguese pre-metric inch (polegada) was defined in 1852 as $2.75 \mathrm{~cm}$, a relatively large unit by international standards. ${ }^{87}$ Having estimated height trends by recruitment period, it turns out that plausible results using this standard are obtained for the recruitment period of 1820-56, but not for the recruitment periods 1763-74 and 1776-1807 (see figure A1). With the Portuguese official measure of $2.75 \mathrm{~cm}$ per inch, the mean height levels of recruits born between 1763 and 1807 would have been almost $10 \mathrm{~cm}$ higher than those measured between 1820 and 1856. Clearly, since the recruitment systems were different, it is possible that they might have led to a stronger selectivity in the eighteenth century. However, this would hardly account for the measurement differential of some $10 \mathrm{~cm}$ detected above.

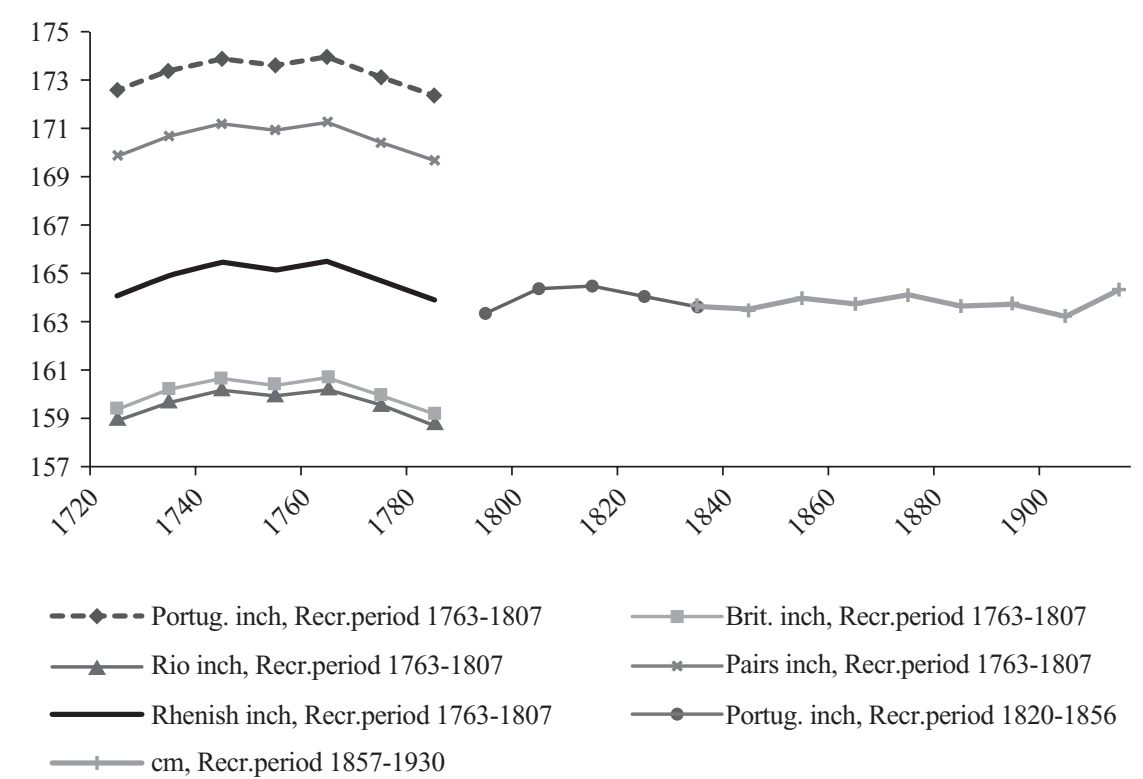

Figure A1. Height development of Portugal, 1720-1910, alternative measures for the pre-1770 period

Sources: See notes to tab. 1.

There are many examples from other countries in which the official measure was not used, but a different measure adopted from other countries instead ${ }^{88}$ After considering the

\footnotetext{
${ }^{87}$ See da Silva Lopes, Memoria, p. 80.

${ }^{88}$ Andalusia, for example, used a French measure during the early nineteenth century; Hueso, 'Fuentes'. In Brazilian prisons, Frank found a yardstick that yielded $2.73 \mathrm{~cm}$ instead of the official $2.75 \mathrm{~cm}$; Frank, 'Stature'. In Argentina, different 'varas' (an Argentinian measure) were used even within in the same district; Silva, 'Dimensiones'.
} 
historical context, we compared various possible measures with the level of the 1780 s. Candidates could be, for example, the inch equivalents used in the large intercontinental empires of the time: the British, French, and Dutch empires. The 'Rhenish inch' used in the Dutch Empire was $2.6154 \mathrm{~cm}$, and the British inch was $2.54 \mathrm{~cm}$. The French (Paris) inch was nearly as large as the Portuguese one $(2.707 \mathrm{~cm})$. The measure used in the Portuguese colony of Brazil (Rio de Janeiro inch: $2.5327 \mathrm{~cm}$ ) might also be a plausible candidate. Comparing these inch measures to the 1790 s birth cohort of the 1820-56 recruitment period, we found that by far the most plausible was the Rhenish inch. The height levels of the 1780 s according to the recruitment regime of 1776-1807 were quite similar to the heights of the 1790s birth cohort of the 1820-56 recruitment system. Other measures in contrast would result in a strong positive or negative divergence. Is it plausible that a Rhenish (Dutch and North German) measure was used in Portugal? The Netherlands were an important trading partner, and often measures were exported to countries which officially had their own measures (the unit was exported to Russia, for example). Most important, the restructuring of the Portuguese army in the 1760s, under Count Schaumburg-Lippe, a North German, bureaucratic and measurement enthusiast, could have inspired the adoption of the Rhenish measure. This continued for a few decades, until the national standardization of measures during the early nineteenth century implied a switch to the official Portuguese measure. We find some evidence in the literature that Count Schaumburg-Lippe had, in fact, manipulated the measure. In 1763, we find an instruction on the minimum height requirement applied during that period, which refers to 62 'Polegadas alargadas', which means 'extended', 'broadened', or 'widened' inches. As applying an inch that equals even more than $2.75 \mathrm{~cm}$ would not be plausible, in this case we conclude that the 'extension' referred to the increased number of inches for a given stature. In other words, this measure yielded more inches than in the case of the normal inch, and was therefore 'alargada'. Hence, we conclude that the Rhenish measure was used and apply this in our analysis.

\section{APPENDIX II: ESTIMATES OF THE RECRUITMENT PERIODS OF 1763-74 AND 1776-1807, COMPARED TO THE RECRUITMENT PERIOD OF 1763-74 ONLY}

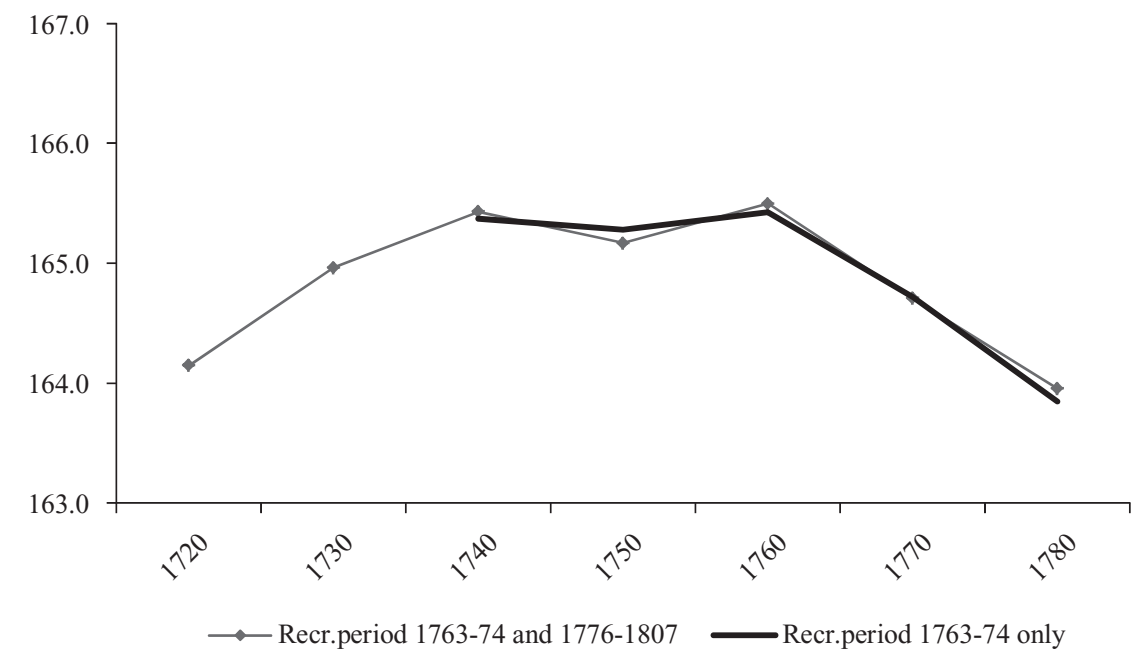

Sources: See notes to tab. 1. 


\section{APPENDIX III: OVERLAPPING BIRTH DECADES: WERE RECRUITS BORN IN THE SAME BIRTH DECADE, BUT MEASURED UNDER DIFFERENT RECRUITMENT REGIMES, SIGNIFICANTLY DIFFERENT IN HEIGHT?}

\begin{tabular}{lccc}
\hline Recruitment regimes compared & $\begin{array}{c}1763-74 \text { versus } \\
1776-1807\end{array}$ & $\begin{array}{c}1776-1807 \text { versus } \\
1820-56\end{array}$ & $\begin{array}{c}1820-56 \text { versus } \\
1857-1932\end{array}$ \\
\hline Birth decade studied & $1740 \mathrm{~s}$ & $1780 \mathrm{~s}$ & $1830 \mathrm{~s}$ \\
Regional dummies & Yes & Yes & Yes \\
Occupation dummies & Yes & Yes & Yes \\
Grenadier/officer dummies & Yes & Yes & Yes \\
Dummy period 1763-74 & 0.76 & & \\
Dummy period 1776-1807 & $(0.367)$ & 0.26 & 0.83 \\
Dummy period 1820-56 & & $(0.851)$ & $(0.275)$ \\
Constant & & & $164.58^{* * *}$ \\
$\mathrm{~N}$ & $165.56^{* * *}$ & $165.97^{* * *}$ & $(0.000)$ \\
\hline
\end{tabular}

Notes: *** Significant at the $1 \%$ level.

Only adult recruits (aged 22-45) are included, because including the younger recruits would have yielded unreliable coefficients due to the small sample sizes for the individual ages. Among the birth decade of the 1740s (col. 1), 121 recruits were measured under the 1763-74 recruitment regime, and 30 under the 1776-1807 recruitment regime. The respective figures for col. 2 , 1776-1807 and 1820-56 (birth decade 1780s) are 38 and 22; for col. 3,105 and 773. The 1780s measured under recruitment regime $1776-1807$ in the general trend estimate could be included, because there were sufficient 18- to 21 -year-olds to exceed the $\mathrm{N}=50$ minimum.

Sources: See notes to tab. 1 .

\section{APPENDIX IV: THE SIZE OF THE PORTUGUESE ARMY}

Do we have figures for the size of the Portuguese army at least for some benchmark years in the eighteenth and nineteenth centuries? We have actually two sources for the size of the army. One study presents simply the official numbers, but these official numbers were often exaggerated to further diplomatic and political aims (see table A2). This study does not attempt to represent the reality of army size. The other source is Dores Costa, which refers to estimates of actual strength. However, his data stop around 1800. From around 1850, the official figures reported by Pereira Marques seem plausible and can be accepted as reflecting reality until about $1900 .{ }^{89}$

According to Dores Costa, in 1712 the permanent army consisted of about 25,000 soldiers and included 19,500 infantry and 5,000 cavalry. There was an additional substantial contingent of militia men who were selected in a different way, and not really part of the standing army. Those who signed up for the militia were not liable for military service. In 1735 , the standing army was supposed to be 31,000 . This was a moment of diplomatic tension with Spain. In 1750, total army figures were $18,000 .{ }^{90}$

The year 1762 started with 9,000 foot soldiers, but the threat of war raised this officially to 40,000 total soldiers, a fiction for use in diplomacy. The actual size was 15,000 foot and 4,000 cavalry. In 1791, the army totalled 19,000. At the very end of the eighteenth century, the threshold of 20,000 was overtaken for the first time since the war of independence from Spain in the middle of the seventeenth century. Again, the official figures were substantially higher around 1800 compared to reality. ${ }^{91}$

\footnotetext{
${ }^{89}$ Dores Costa, Insubmissão; Pereira Marques, Exército.

${ }^{90}$ Dores Costa, Insubmissão, pp. 63-4; Pereira Marques, Exército, p. 52.

${ }^{91}$ Dores Costa, Insubmissão, pp. 65-6; Pereira Marques, Exército, p. 52.
} 
Comparing the true figures of the eighteenth century and the official figures of the mid-nineteenth century, the differences are modest. Pereira Marques reports between 20,000 and 30,000 in the 1830 s to 1850 s. Those recruitment years correspond to the birth decades of the 1800 s to $1830 \mathrm{~s} .{ }^{92}$ Until this period, Portuguese height development remained quite similar to the trends in other European countries (see figure 4). Only afterwards did Portugal fall behind, during a time when its army size remained quite constant. In the meantime, the Portuguese population grew from 2 million in 1700, to 3.3 million in 1820, and 5.4 million in 1900. Hence, over time, the ratio of soldiers to population might have actually declined.

Table A2. Official size of the Portuguese army (in thousands)

\begin{tabular}{ccc}
\hline Year & Infantry & Total \\
\hline 1762 & 40 & 48 \\
1776 & 29 & 38 \\
1796 & 38 & 51 \\
1800 & 28 & 38 \\
1812 & 34 & 52 \\
1814 & 24 & 41 \\
1816 & 37 & 57 \\
1821 & 18 & 30 \\
1832 & 24 & 41 \\
1834 & 16 & 26 \\
1837 & 14 & 29 \\
1850 & 13 & 25 \\
\hline
\end{tabular}

Notes: These data are official figures drawn from legislation setting the size of the armed forces in each of these years. They do not constitute estimates of the actual size of the armed forces.

Source: Pereira Marques, Exército, p. 52.

${ }^{92}$ Pereira Marques, Exército, p. 52. 